\title{
Methane fluxes in the high northern latitudes for 2005-2013 estimated using a Bayesian atmospheric inversion
}

\author{
Rona L. Thompson ${ }^{1}$, Motoki Sasakawa ${ }^{2}$, Toshinobu Machida ${ }^{2}$, Tuula Aalto ${ }^{3}$, Doug Worthy ${ }^{4}$, Jost V. Lavric ${ }^{5,6}$, \\ Cathrine Lund Myhre ${ }^{1}$, and Andreas Stohl ${ }^{1}$ \\ ${ }^{1}$ NILU - Norwegian Institute for Air Research, Kjeller, Norway \\ ${ }^{2}$ National Institute for Environmental Studies, Tsukuba, Japan \\ ${ }^{3}$ Finnish Meteorological Institute (FMI), Helsinki, Finland \\ ${ }^{4}$ Environment Canada, Toronto, Canada \\ ${ }^{5}$ Max Planck Institute for Biogeochemistry, Jena, Germany \\ ${ }^{6}$ Integrated Carbon Observation System (ICOS), ERIC Head Office, Helsinki, Finland \\ Correspondence to: Rona L. Thompson (rlt@nilu.no)
}

Received: 21 July 2016 - Discussion started: 30 September 2016

Revised: 13 February 2017 - Accepted: 16 February 2017 - Published: 14 March 2017

\begin{abstract}
We present methane $\left(\mathrm{CH}_{4}\right)$ flux estimates for 2005 to 2013 from a Bayesian inversion focusing on the high northern latitudes (north of $50^{\circ} \mathrm{N}$ ). Our inversion is based on atmospheric transport modelled by the Lagrangian particle dispersion model FLEXPART and $\mathrm{CH}_{4}$ observations from 17 in situ and five discrete flask-sampling sites distributed over northern North America and Eurasia. $\mathrm{CH}_{4}$ fluxes are determined at monthly temporal resolution and on a variable grid with maximum resolution of $1^{\circ} \times 1^{\circ}$. Our inversion finds a $\mathrm{CH}_{4}$ source from the high northern latitudes of 82 to $84 \mathrm{Tg} \mathrm{yr}^{-1}$, constituting $\sim 15 \%$ of the global total, compared to 64 to $68 \mathrm{Tg} \mathrm{yr}^{-1}(\sim 12 \%)$ in the prior estimates. For northern North America, we estimate a mean source of 16.6 to $17.9 \mathrm{Tg} \mathrm{yr}^{-1}$, which is dominated by fluxes in the Hudson Bay Lowlands (HBL) and western Canada, specifically the province of Alberta. Our estimate for the HBL, of 2.7 to $3.4 \mathrm{Tg} \mathrm{yr}^{-1}$, is close to the prior estimate (which includes wetland fluxes from the land surface model, LPXBern) and to other independent inversion estimates. However, our estimate for Alberta, of 5.0 to $5.8 \mathrm{Tg} \mathrm{yr}^{-1}$, is significantly higher than the prior (which also includes anthropogenic sources from the EDGAR-4.2FT2010 inventory). Since the fluxes from this region persist throughout the winter, this may signify that the anthropogenic emissions are underestimated. For northern Eurasia, we find a mean source of 52.2 to $55.5 \mathrm{Tg} \mathrm{yr}^{-1}$, with a strong contribution from fluxes in the Western Siberian Lowlands (WSL) for which we es-
\end{abstract}

timate a source of 19.3 to $19.9 \mathrm{Tg} \mathrm{yr}^{-1}$. Over the 9-year inversion period, we find significant year-to-year variations in the fluxes, which in North America, and specifically in the HBL, appear to be driven at least in part by soil temperature, while in the WSL, the variability is more dependent on soil moisture. Moreover, we find significant positive trends in the $\mathrm{CH}_{4}$ fluxes in North America of 0.38 to $0.57 \mathrm{Tg} \mathrm{yr}^{-2}$, and northern Eurasia of 0.76 to $1.09 \mathrm{Tg} \mathrm{yr}^{-2}$. In North America, this could be due to an increase in soil temperature, while in North Eurasia, specifically Russia, the trend is likely due, at least in part, to an increase in anthropogenic sources.

\section{Introduction}

Atmospheric methane $\left(\mathrm{CH}_{4}\right)$ increased globally during the 20th century, from a pre-industrial value of approximately $722 \mathrm{ppb}$ (Etheridge et al., 1998) to $1773 \mathrm{ppb}$ in 1999 (Kirschke et al., 2013), largely due to an increase in anthropogenic sources. The upward trend was interrupted between 1999 and 2006, when the atmospheric growth rate of $\mathrm{CH}_{4}$ was close to zero but resumed again around 2007 (Dlugokencky et al., 2011; Kirschke et al., 2013; Nisbet et al., 2014 ) and, in 2014, the growth rate was substantially faster $\left(12.5 \mathrm{ppb} \mathrm{yr}^{-1}\right)$ than in any other year since 2007 (Nisbet et al., 2016). Changes in the atmospheric growth rate indicate changes in the balance of $\mathrm{CH}_{4}$ sources and sinks; however, 
the cause of the 1999-2006 stabilization and subsequent rise in atmospheric $\mathrm{CH}_{4}$, and its attribution to different sources is still not fully resolved (Nisbet et al., 2014).

The main $\mathrm{CH}_{4}$ sources are either biogenic such as wetlands, rice paddies, landfills, and enteric fermentation, thermogenic such as fossil fuels, geological seeps, and mud volcanoes or pyrogenic such as the combustion of fossil and bio fuel and biomass (Kirschke et al., 2013, and references therein). Different combinations of sources, particularly wetlands, fossil fuels, and enteric fermentation have been proposed as the reason for the rise of atmospheric $\mathrm{CH}_{4}$ since 2007 (Kirschke et al., 2013; Schaefer et al., 2016; Nisbet et al., 2016). Studies using atmospheric observations in global inversion models have pointed to an increase in tropical wetland emissions as well as in anthropogenic sources, especially fossil fuels, in the temperate Northern Hemisphere after 2006 (Bruhwiler et al., 2014; Bergamaschi et al., 2013). However, anomalously high temperatures in the Arctic in 2007 are thought to have also resulted in higher wetland emissions and, consequently, contributed to the high growth rate of $\mathrm{CH}_{4}$ in the same year (Dlugokencky et al., 2009; Bousquet et al., 2011; Rigby et al., 2008).

In recent decades, the high latitudes have warmed substantially with temperatures in the Arctic increasing at an average rate of $0.38^{\circ} \mathrm{C}$ per decade (Chylek et al., 2009) and the changing climate may have a considerable impact on $\mathrm{CH}_{4}$ sources (Bridgham et al., 2013; AMAP, 2015). The northern high latitudes contain about $44 \%$ of the world's natural wetlands (Lehner and Döll, 2004) and contribute about $24 \mathrm{Tg} \mathrm{yr}^{-1}$, equivalently $26 \%$, to the global natural wetland source of $\mathrm{CH}_{4}$ (Cao et al., 1998). Temperature can impact wetland sources of $\mathrm{CH}_{4}$ directly, by influencing the metabolic rate of methanogens (Christensen et al., 2003, 1996), and indirectly, via permafrost melt and changes to the water table depth, snow cover, and evapotranspiration (Bohn et al., 2007). Other climatic changes in the Arctic, such as increasing sea temperature and sea-ice loss (Stroeve et al., 2007) may also increase the source of $\mathrm{CH}_{4}$ through possible destabilization of methane hydrates in ocean sediments (e.g. Shakhova et al., 2010; Biastoch et al., 2011). In addition to natural sources, the oil and gas industries are particularly important sources in the high northern latitudes, especially in Russia where $20 \%$ of the world's natural gas is produced. With an estimated leak rate of 1 to $10 \%$ of gas production (Hayhoe et al., 2002) this would release 3.5 to $35 \mathrm{Tg} \mathrm{yr}^{-1}$ of $\mathrm{CH}_{4}$. Given the rapid rate of climate change in the high latitudes and possible future expansion of anthropogenic activities in the Arctic it is imperative to have accurate estimates of present-day $\mathrm{CH}_{4}$ emissions, to better understand their natural variability, and to establish any trend.

Atmospheric observations can place a mass balance constraint on emissions and, since they are available quasicontinuously over timescales of several years, can be used to examine inter-annual variations and trends. This method is formalized in atmospheric inversions in which fluxes are found by minimizing a cost function that includes the comparison of the observations and mixing ratios modelled from a prior estimate of the fluxes using a model of atmospheric transport (e.g. Enting, 2002). Until relatively recently, however, atmospheric constraints on $\mathrm{CH}_{4}$ emissions in the high northern latitudes were limited by the scarcity of observations in this region. Until the early 2000s, the ground-based network north of $50^{\circ} \mathrm{N}$ was limited to about 10 discrete sampling sites and three sites with quasi-continuous monitoring (i.e. Barrow in Alaska, and Alert and Fraserdale in Canada). Satellite data in this region are also limited. Satellite measurements of $\mathrm{CH}_{4}$ are made using either thermal infrared (TIR) sounders, such as IASI, or near-infrared (NIR) measurements, such as by the SCIAMACHY instrument (onboard ENVISAT, 2003-2012) and the TANSO instrument (onboard GOSAT, since 2009). However, NIR measurements are limited to the summer and the availability of data is further reduced owing to filtering for aerosols and cloud cover. On the other hand, TIR measurements from IASI have lower sensitivity to near-surface concentrations compared to TANSO or SCIAMACHY and have particularly large biases in the high latitudes (Xiong et al., 2013). Therefore, satellite observations of $\mathrm{CH}_{4}$ from latitudes higher than $50^{\circ}$ are presently not included in global atmospheric inversions (e.g. Bergamaschi et al., 2013; Houweling et al., 2014; Alexe et al., 2015; Monteil et al., 2013).

The observation coverage, however, has recently improved with the establishment of JR-STATION (JapanRussia Siberian Tall Tower Inland Observation Network) (Sasakawa et al., 2010) and the Zotino Tall Tower Observatory (ZOTTO) (Winderlich et al., 2010) in Siberia, the Pallas station in Finland (Aalto et al., 2007), and the Environment Canada (EC) network in Canada (Worthy et al., 2003) (see Fig. 1). Some of the data from these networks/sites have been included in previous inversion studies, however only with limited spatial and temporal coverage: the JR-STATION observations have been used in an inversion focusing on the Siberian lowlands in the year 2010 (Berchet et al., 2015) and the EC observations have been used in an inversion focusing on Canada and the US for 2007 and 2008 (Miller et al., 2014, 2016). We combine observations from all these new networks and stations in an atmospheric inversion for $\mathrm{CH}_{4}$ focusing on the entire region north of $50^{\circ} \mathrm{N}$, and over the period 2005 to 2013, when most observations are available. With the observational constraint of these data, a more accurate estimate of high-latitude fluxes and their inter-annual variability is possible compared to earlier estimates, for which much of these data were not available (e.g. Bruhwiler et al., 2014; Bergamaschi et al., 2013).

In Sect. 2, we present an overview of the inversion method and a description of its various components, including the observations, the atmospheric transport modelling, and the a priori fluxes. In Sect. 3, we analyse the performance of the inversions and compare the results to independent observations, i.e. data not used in the inversion. Section 4 discusses 


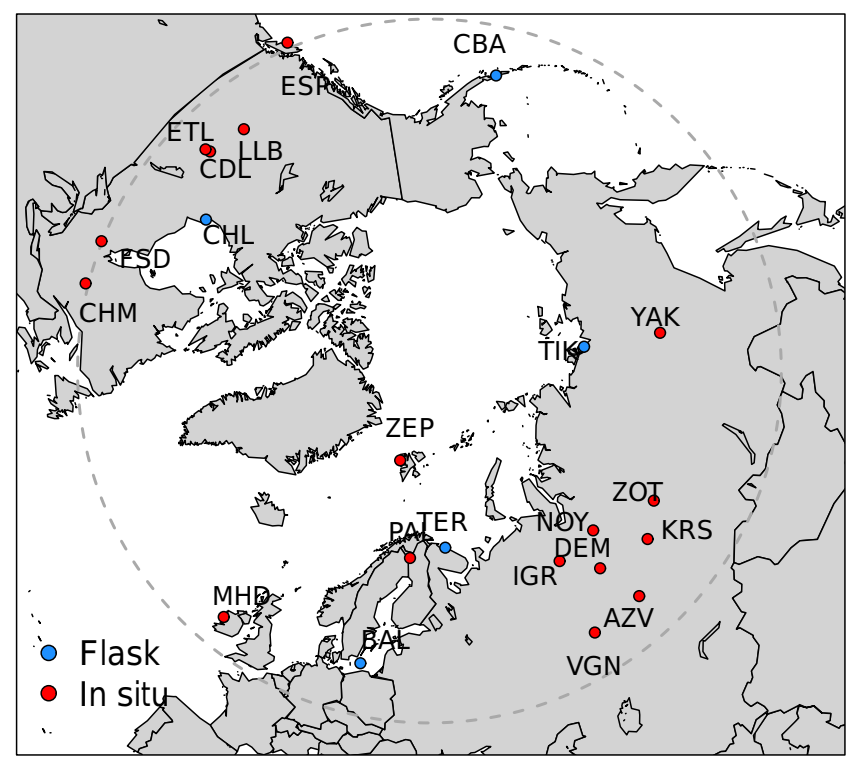

Figure 1. Map showing the atmospheric measurement sites used in the inversion. The grey dashed line indicates the southern boundary of the inversion domain at $50^{\circ} \mathrm{N}$. Flask-air sampling sites are indicated in blue and in situ sites in red.

the spatial and temporal variability of the a posteriori fluxes and evidence for trends.

\section{Methodology}

\subsection{Overview of the inversion framework}

In this study we use the Bayesian inversion framework FLEXINVERT, which is based on the Lagrangian particle dispersion model FLEXPART (Stohl, 1998; Stohl et al., 2005) and is fully described in Thompson and Stohl (2014) and has been previously used for $\mathrm{CH}_{4}$ inversions (Thompson et al., 2015). FLEXINVERT uses so-called flux sensitivities (or source-receptor relationships) calculated by FLEXPART, which describe the relationship between a flux over a given area and time interval, and the associated change in atmospheric mixing ratio (in this case of $\mathrm{CH}_{4}$ ) at another time and location (see Sect. 2.2). FLEXINVERT finds the optimal $\mathrm{CH}_{4}$ fluxes by minimizing the mismatch between modelled and observed mixing ratios with a constraint imposed by prior information and its uncertainty. This is described by the cost function

$$
\begin{aligned}
J(\boldsymbol{x}) & =\frac{1}{2}\left(\boldsymbol{x}-\boldsymbol{x}_{b}\right)^{\mathrm{T}} \mathbf{B}^{-1}\left(\boldsymbol{x}-\boldsymbol{x}_{b}\right) \\
& +\frac{1}{2}(\boldsymbol{y}-\mathbf{H} \boldsymbol{x})^{\mathrm{T}} \mathbf{R}^{-1}(\boldsymbol{y}-\mathbf{H} \boldsymbol{x}),
\end{aligned}
$$

where $\boldsymbol{x}_{b}$ and $\boldsymbol{x}$ are respectively the prior and posterior state vectors of surface fluxes and $\mathbf{H}$ is a Jacobian matrix of flux sensitivities, which relates the fluxes to the observed mix- ing ratios, $\boldsymbol{y}$. The observation-model and posterior-prior flux mismatches are weighted by their uncertainties, described by the error covariance matrices, $\mathbf{R}$ and $\mathbf{B}$, respectively. The optimized state vector is found by solving the first-order derivative of the cost function:

$J^{\prime}(\boldsymbol{x})=\mathbf{B}^{-1}\left(\boldsymbol{x}-\boldsymbol{x}_{b}\right)-\mathbf{H}^{\mathrm{T}} \mathbf{R}^{-1}(\boldsymbol{y}-\mathbf{H} \boldsymbol{x})=0$.

FLEXINVERT takes advantage of the fact that in this case $\mathbf{H}$ is a matrix operator and solves Eq. (2) directly (i.e. analytically).

The second-order derivative of the cost function is equal to the reciprocal of the posterior uncertainty. Although this could be used to calculate the posterior uncertainty, we find for our inversion framework that this leads to an underestimate of the uncertainty. This is because the matrix B is not stored in computer memory but rather its eigen decomposition with truncation of the smallest $0.01 \%$ of eigenvalues and their corresponding eigenvectors. For this reason, we use a Monte Carlo approach to calculate the posterior uncertainty following Chevallier et al. (2005).

We optimize the fluxes at monthly temporal resolution and on a grid of varying spatial resolution (with a finest resolution of $1^{\circ} \times 1^{\circ}$; see Sect. 2.4 and Fig. 2) over the period 2005 2013. The various components of the inversion framework are described in the following sections.

\subsection{Atmospheric observations}

In this study, we make use of relatively new stations measuring $\mathrm{CH}_{4}$ dry-air mole fractions (units of $\mathrm{nmol} \mathrm{mol}^{-1}$ or parts per billion, ppb) established in Siberia, Europe, and Canada (see Fig. 1 and Table 1). The JR-STATION network was established in 2004 and has expanded to a total of nine tall tower sites with in situ measurements of $\mathrm{CH}_{4}$ (Sasakawa et al., 2010). Measurements of $\mathrm{CH}_{4}$ are made using a semiconductor sensor based on a tin dioxide natural gas leak detector that was developed for atmospheric measurements by Suto and Inoue (2010). The measurements have a repeatability of $3 \mathrm{ppb}$ and are reported on the NIES-94 scale. The tall towers have two sampling inlets at different heights, each of which is sampled for $20 \mathrm{~min}$ during a $1 \mathrm{~h}$ period (Sasakawa et al., 2010). In this study we use observations from seven towers and only from the upper inlets, which have heights between 43 and $85 \mathrm{~m}$ above ground level (m a.g.l.). Three towers (KRS, DEM, and NOY) are surrounded by taiga forest and wetlands. The IGR tower is located in a small town (population $\sim 10000$ ) by the Ob River and is also surrounded by wetlands, the AZV and VGN towers are located in steppe regions, and the YAK tower is located in the East Siberian Taiga (for details see Sasakawa et al., 2010).

EC established two in situ measurement sites more than 20 years ago, ALT and FSD, but since the early 2000s the network has expanded considerably. In this study, we include six sites, which have records of at least 4 years. Throughout most of this study, the measurements were made with 
Table 1. Atmospheric measurement sites included in the inversion.

\begin{tabular}{|c|c|c|c|c|c|c|}
\hline Station & ID & Network & Latitude & Longitude & Altitude (m) & Time period \\
\hline Zeppelin $^{c}$ & ZEP & NILU & $78.9^{\circ} \mathrm{N}$ & $11.9^{\circ} \mathrm{E}$ & 479 & 2004-2013 \\
\hline Tiksi & TIK & NOAA & $71.6^{\circ} \mathrm{N}$ & $128.9^{\circ} \mathrm{E}$ & 43 & 2011-2013 \\
\hline Teriberka $^{c}$ & TER & MGO & $69.2^{\circ} \mathrm{N}$ & $35.1^{\circ} \mathrm{E}$ & 40 & 2004-2013 \\
\hline Pallas ${ }^{c}$ & PAL & FMI & $68.0^{\circ} \mathrm{N}$ & $24.1^{\circ} \mathrm{E}$ & 565 & 2004-2013 \\
\hline Noyabrsk & NOY & JRS & $63.4^{\circ} \mathrm{N}$ & $75.8^{\circ} \mathrm{E}$ & 143 & 2005-2013 \\
\hline $\operatorname{Igrim}^{\mathrm{c}}$ & IGR & JRS & $63.2^{\circ} \mathrm{N}$ & $64.4^{\circ} \mathrm{E}$ & 72 & 2005-2013 \\
\hline Yakutsk & YAK & JRS & $62.1^{\circ} \mathrm{N}$ & $129.4^{\circ} \mathrm{E}$ & 287 & 2007-2013 \\
\hline ZOTTO & ZOT & MPI & $60.8^{\circ} \mathrm{N}$ & $89.4^{\circ} \mathrm{E}$ & 125 & 2009-2013 \\
\hline Demyanskoe $^{c}$ & DEM & JRS & $59.8^{\circ} \mathrm{N}$ & $70.9^{\circ} \mathrm{E}$ & 138 & 2005-2013 \\
\hline Churchill & CHL & $\mathrm{EC}$ & $58.8^{\circ} \mathrm{N}$ & $94.1^{\circ} \mathrm{W}$ & 35 & 2007-2013 \\
\hline Karasevoe $^{c}$ & KRS & JRS & $58.3^{\circ} \mathrm{N}$ & $82.4^{\circ} \mathrm{E}$ & 117 & 2004-2013 \\
\hline Baltic Sea & BAL & NOAA & $55.5^{\circ} \mathrm{N}$ & $16.7^{\circ} \mathrm{E}$ & 28 & 2004-2011 \\
\hline Cold Bay ${ }^{c}$ & CBA & NOAA & $55.2^{\circ} \mathrm{N}$ & $162.7^{\circ} \mathrm{W}$ & 25 & 2004-2013 \\
\hline Lac La Biche ${ }^{c}$ & LLB & $\mathrm{EC}$ & $55.0^{\circ} \mathrm{N}$ & $112.5^{\circ} \mathrm{W}$ & 546 & $2004-2013^{a}$ \\
\hline Azovo & $\mathrm{AZV}$ & JRS & $54.7^{\circ} \mathrm{N}$ & $73.0^{\circ} \mathrm{E}$ & 150 & 2009-2013 \\
\hline Vaganovo & VGN & JRS & $54.5^{\circ} \mathrm{N}$ & $62.3^{\circ} \mathrm{E}$ & 285 & 2008-2013 \\
\hline East Trout Lake & ETL & $\mathrm{EC}$ & $54.4^{\circ} \mathrm{N}$ & $105.0^{\circ} \mathrm{W}$ & 492 & 2005-2013 \\
\hline Candle Lake & $\mathrm{CDL}$ & $\mathrm{EC}$ & $53.9^{\circ} \mathrm{N}$ & $104.7^{\circ} \mathrm{W}$ & 489 & 2004-2007 \\
\hline Mace Head ${ }^{\mathrm{c}}$ & MHD & AGAGE & $53.3^{\circ} \mathrm{N}$ & $9.9^{\circ} \mathrm{W}$ & 25 & 2004-2013 \\
\hline Fraserdale $^{c}$ & FSD & $\mathrm{EC}$ & $49.9^{\circ} \mathrm{N}$ & $81.6^{\circ} \mathrm{W}$ & 210 & 2004-2013 \\
\hline Chibougamau & $\mathrm{CHM}$ & $\mathrm{EC}$ & $49.7^{\circ} \mathrm{N}$ & $74.3^{\circ} \mathrm{W}$ & 393 & 2007-2010 \\
\hline Estevan Point $^{\mathrm{c}}$ & ESP & $\mathrm{EC}$ & $49.4^{\circ} \mathrm{N}$ & $126.6^{\circ} \mathrm{W}$ & 39 & $2004-2013^{b}$ \\
\hline
\end{tabular}

${ }^{a}$ Flask samples from NOAA 2004-2007 and continuous thereafter. ${ }^{\text {b }}$ Flask samples 2004-2009 and continuous thereafter.

${ }^{c}$ Sites used in scenario S3.

approximately hourly resolution using gas chromatographs equipped with flame ionization detectors (GC-FID) and are reported on the WMOX2004 scale. However, at LLB and FSD the GC-FID instruments were replaced by cavity ringdown spectroscopy (CRDS) instruments in 2012 and 2013, respectively. FSD is located on the southern perimeter of the Hudson Bay Lowlands and is surrounded by boreal forest, and the closest town is approximately $70 \mathrm{~km}$ away (population of $\sim 2500$ ). CDL is in the province of Saskatchewan and is also surrounded by boreal forest, and the closest town is $100 \mathrm{~km}$ away (population of $\sim 35000$ ). ETL was established to replace CDL, which was discontinued in 2008. ETL is located $40 \mathrm{~km}$ away from CDL at the site of a $106 \mathrm{~m}$ high communication tower (compared to the $28 \mathrm{~m}$ high tower at CDL) and is also surrounded by boreal forest. LLB is located in a region of peatland and boreal forest in the province of Alberta and is approximately $200 \mathrm{~km}$ away from the city of Edmonton (population $\sim 800000$ ). CHM is located in a boreal forest in eastern Canada in a cool humid climate. CHL is located on the southern coast of the Hudson Bay with boreal forest to the south and Arctic tundra to the northwest. Flask-air sampling began at CHL in May 2007 and in situ measurements in October 2011.

The Pallas station is located in northern Finland in an area of wetlands with some lakes and patches of forest (Aalto et al., 2007). Continuous $\mathrm{CH}_{4}$ measurements have been made from 2004 to 2009 using a GC-FID instrument and, since
2009, using a CRDS instrument. The data are reported on the WMOX2004 scale and have an average repeatability of $1.5 \mathrm{ppb}$. Air is sampled from an inlet at $7 \mathrm{~m}$ a.g.l.

ZOTTO (http://www.zottoproject.org/) is a tall tower site surrounded by light taiga forest interspersed with bogs and has a $\mathrm{CH}_{4}$ time series available since 2009 (Winderlich et al., 2010). The measurements are made using a CRDS instrument and buffer volumes on each sample line, which allows a continuous, near-concurrent measurement of air from six heights. For this study, we use data from the uppermost level at $301 \mathrm{~m}$ a.g.l. Data from each height are reported at circa 20 min intervals on the WMOX2004 scale with a repeatability of $0.3 \mathrm{ppb}$ (Winderlich et al., 2010).

The Zeppelin observatory is located on a mountaintop on the island of Spitsbergen (the largest island of Svalbard) and has a $\mathrm{CH}_{4}$ record dating from 2001. Methane measurements were made using a GC-FID until April 2012 and were reported hourly with a repeatability of $3 \mathrm{ppb}$ (from 2004 to 2012). In April 2012, the GC-FID was replaced by a CRDS instrument and data since then are reported with a repeatability of $0.2 \mathrm{ppb}$ at $1 \mathrm{~min}$ time resolution. Up until spring 2011, air was sampled from $2 \mathrm{~m}$ above the roof at the Zeppelin observatory and from then on, from a $15 \mathrm{~m}$ tall mast. The whole time series from August 2001 has been reprocessed as a part of the harmonization of historic concentration measurements within the European Commission FP7 project InGOS (http://www.ingos-infrastructure.eu/). 

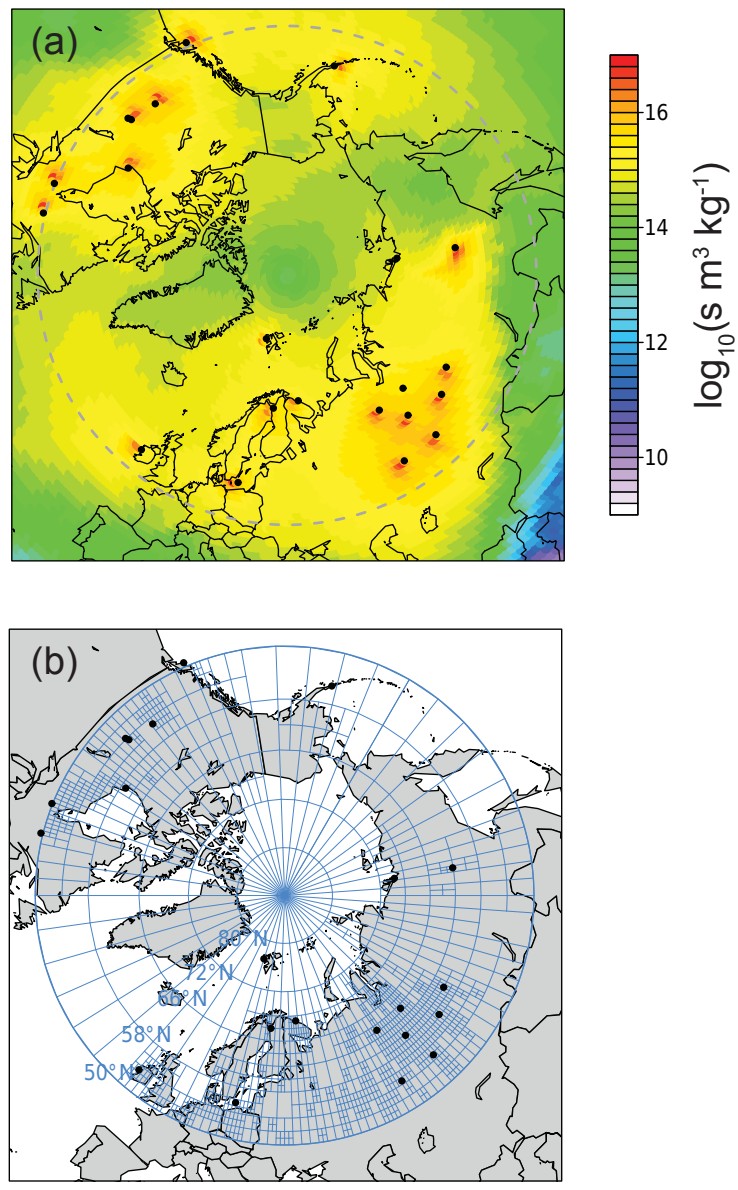

Figure 2. The annual mean emission sensitivity of all sites shown for 2009 (units of $\log _{10}\left(\mathrm{~s} \mathrm{~m}^{3} \mathrm{~kg}^{-1}\right)$ ) with the southern domain boundary shown by the grey dashed line (a) and the grid used in the inversion based on the mean emission sensitivity (b). The sites used in the inversion are indicated by the black points.

The NOAA flask-air sampling network includes eight sites north of $50^{\circ} \mathrm{N}$ (Dlugokencky et al., 2015). In this study, we use five of these sites that sample predominantly background air to define the initial mixing ratios (see Sect. 2.5) and the remaining three sites (BAL, CBA, and TIK) are used in the inversion. Discrete samples in the NOAA network are taken at approximately weekly frequency and are analysed in a central laboratory using a GC-FID. The concentrations are reported on the WMOX2004 scale and have a long-term repeatability of $2 \mathrm{ppb}$.

All data were adjusted to the WMOX2004 scale using the results of the World Meteorological Organization Round Robin Comparison Experiment (http://www.esrl.noaa.gov/ gmd/ccgg/wmorr/). We assimilated the in situ observations as daily afternoon (between 12:00 and 16:00 local time) averages and the discrete observations without data selection or averaging as these samples are normally taken during daytime when the boundary layer is well mixed. Further data selection is performed on the in situ observations and is discussed in Sect. 2.6.

\subsection{Prior information}

For wetland fluxes, we compare estimates from two different land surface models (Fig. 3). The first is the LPX-Bern model (Land Surface Processes and Exchanges model of the University of Bern) (Spahni et al., 2013). LPX-Bern calculates $\mathrm{CH}_{4}$ fluxes monthly at $1^{\circ} \times 1^{\circ}$ resolution for peatlands, inundated wetlands, wet and dry mineral soils, and rice paddies. LPX-Bern is driven by CRU climate data (version TS-3.23, https://crudata.uea.ac.uk/cru/data/hrg/) and the wetland fraction and water table depth in each grid cell are calculated dynamically using the DYPTOP model (DYnamical Peatland model based on TOPmodel) (Stocker et al., 2014). The second model is LPJ-DGVM (Lund-PotsdamJena Dynamic Global Vegetation Model; Bergamaschi et al., 2007). LPJ-DGVM uses monthly mean temperature, cloud fraction and total precipitation, as well as a fixed wetland area based on land-cover maps (Bergamaschi et al., 2007). In LPJ-DGVM substrate availability for methanogenesis is represented as the total soil respiration rate, which integrates the fast-turnover soil organic matter pool and soil temperature, and the water table depth is based on soil moisture (Bergamaschi et al., 2007). LPJ-DGVM calculates monthly $\mathrm{CH}_{4}$ fluxes at $1^{\circ} \times 1^{\circ}$ resolution for inundated wetlands, wet soils, and peatlands, but does not calculate the uptake of $\mathrm{CH}_{4}$ by dry soils or the emissions from rice paddies. For the dry soil flux of $\mathrm{CH}_{4}$, we use the monthly climatology of Ridgwell et al. (1999) (also at $1^{\circ} \times 1^{\circ}$ resolution), which has a similar seasonality and magnitude to that in LPX-Bern, with maximum uptake in July. For rice paddies, we use the estimate from the Emissions Database for Global Atmospheric Research (EDGAR-v4.2 FT2010, from hereon, EDGAR) with monthly emission factors from Matthews et al. (1991).

For the anthropogenic sources, which include emissions from enteric fermentation in domestic animals, oil, gas, and coal exploitation, and landfills, we use annual estimates from EDGAR, which are provided at $0.1^{\circ} \times 0.1^{\circ}$ resolution. Since EDGAR is only available up to 2010, we used the 2010 emissions also for the years 2011 to 2013. Estimates of emissions from biomass burning were taken from the Global Fire Emissions Database (GFED-v3) (van der Werf et al., 2010), which are provided at monthly and at $0.5^{\circ} \times 0.5^{\circ}$ resolution. For ocean fluxes of $\mathrm{CH}_{4}$, we use the monthly climatology at $1^{\circ} \times 1^{\circ}$ resolution from Lambert and Schmidt (1993) and for the emissions from wild ruminant animals and termites, we use the monthly climatologies of Houweling et al. (1999) and Sanderson et al. (1996), respectively, both at $1^{\circ} \times 1^{\circ}$ resolution. The different soil flux estimates, i.e. LPX-Bern and LPJ-DGVM, form the basis of two different prior fluxes and, correspondingly, inversion scenarios, S1 and S2 (for an overview of the prior fluxes, see Table 2). 
Table 2. Prior fluxes (units $\mathrm{Tg}^{-1}$ ) by source type for 2009. For the wetland fluxes, two different models were used to form sets of prior fluxes for scenarios S1 and S2.

\begin{tabular}{|c|c|c|c|c|c|c|c|}
\hline \multicolumn{2}{|c|}{ Source type } & \multicolumn{2}{|c|}{ Dataset } & \multicolumn{2}{|c|}{ Globally } & \multicolumn{2}{|c|}{$>50^{\circ} \mathrm{N}$} \\
\hline & & $\mathrm{S} 1$ & $\mathrm{~S} 2$ & $\mathrm{~S} 1$ & $\mathrm{~S} 2$ & $\mathrm{~S} 1$ & S2 \\
\hline \multirow[t]{6}{*}{ Natural } & Wetlands & LPX-Bern & LPJ-DGVM & 202 & 175 & 25 & 27 \\
\hline & Termites & Sanderson et al. (1996) & Sanderson et al. (1996) & 19 & 19 & 0 & 0 \\
\hline & Wild animals & Houweling et al. (1999) & Houweling et al. (1999) & 5 & 5 & 1.2 & 1.2 \\
\hline & Ocean & Lambert and Schmidt (1993) & Lambert and Schmidt (1993) & 17 & 17 & 5.3 & 5.3 \\
\hline & Soil oxidation & LPX-Bern & Ridgwell et al. (1999) & -49 & -38 & -6.5 & -4.3 \\
\hline & Biomass burning & GFED3.1 & GFED3.1 & 13 & 13 & 1.2 & 1.2 \\
\hline \multirow[t]{4}{*}{ Anthropogenic } & Fuel and industry & EDGARv4.2-FT2010 & EDGARv4.2-FT2010 & 150 & 150 & 25 & 25 \\
\hline & Enteric ferment & EDGAR v4.2-FT2010 & EDGAR v4.2-FT2010 & 101 & 101 & 6.5 & 6.5 \\
\hline & Waste & EDGAR v4.2-FT2010 & EDGAR v4.2-FT2010 & 61 & 61 & 7.0 & 7.0 \\
\hline & Rice cultivation & LPX-Bern & EDGAR v4.2-FT2010 & 36 & 38 & 0.04 & 0.02 \\
\hline Total & & & & 556 & 541 & 65 & 69 \\
\hline
\end{tabular}

Prior flux uncertainties were calculated as $50 \%$ of the flux in each grid cell with minimum and maximum values of $1 \times 10^{-12}$ and $1 \times 10^{-6} \mathrm{~kg} \mathrm{~m}^{-2} \mathrm{~h}^{-1}$, respectively. The prior flux error covariance matrix, $\mathbf{B}$, was calculated as the Kronecker product of the temporal and spatial covariance matrices, which were calculated using an exponential decay model and a temporal scale length of 90 days and spatial scale lengths of $500 \mathrm{~km}$ over land and $2000 \mathrm{~km}$ over ocean. The square root of the sum of all elements in the error covariance matrix was scaled to $15 \mathrm{Tg} \mathrm{yr}^{-1}$, representing $\sim 25 \%$ of the total area integrated flux in the domain.

\subsection{Flux sensitivities}

The flux sensitivities are calculated using the backwards mode of FLEXPART, in which virtual particles are followed backwards in time from the observation times and locations (from hereon referred to as "receptors"). At 3-hourly intervals, 10000 virtual particles were released and followed backwards in time for 10 days to any point on the globe. Ten days was considered an appropriate timescale since after several days backwards in time the particles are well dispersed (well mixed) and the influence of fluxes from a specific location becomes very small. Flux sensitivities are calculated as proportional to the average residence time of $P$ backtrajectories in a given grid cell (in the model layer $0-400 \mathrm{~m}$ ) and time step $(i, n)$ :

$\frac{\partial y}{\partial x}=\frac{1}{P} \sum_{p=1}^{P} \frac{\Delta t_{i, p, n}^{\prime}}{\rho_{i, n}}$,

where $\rho_{i, n}$ is the air density and $\Delta t_{i, p, n}^{\prime}$ is the residence time of trajectory $p$ in the spatio-temporal grid cell $(i, n)$ (for details see Seibert and Frank, 2004). FLEXPART simulations were made using European Centre for Medium-Range Weather Forecasts ERA-Interim (ECMWF EI) meteorologi- cal analyses with a $12 \mathrm{~h}$ analysis window and a spatial resolution of approximately $80 \mathrm{~km}$ (T255) on 60 vertical levels. The analyses were gridded to $1.0^{\circ} \times 1.0^{\circ}$ and interpolated to 3-hourly fields. EI was chosen over the higher-resolution operational data because of its long-term consistency. Loss of $\mathrm{CH}_{4}$ due to oxidation by $\mathrm{OH}$ radicals was also calculated along the trajectories using pre-calculated $\mathrm{OH}$ fields from the GEOS-Chem model (Bey et al., 2001). However, over the 10-day calculation period the loss is generally small, i.e. $\sim 1 \mathrm{ppb}$.

The average flux sensitivity of all receptors over the year 2009 is used to define a grid of varying spatial resolution for the inversion (the grid was kept constant throughout the 9-year inversion). This grid has maximum resolution of $1.0^{\circ} \times 1.0^{\circ}$ in regions where there is a strong contribution from fluxes to the change in $\mathrm{CH}_{4}$ mixing ratios at the measurement sites and decreasing resolution in steps of factor two up to $8.0^{\circ} \times 8.0^{\circ}$ in regions where there is only a weak contribution (Thompson and Stohl, 2014; Stohl et al., 2010) (Fig. 2). In this way, the number of state variables is reduced without significantly increasing the aggregation error.

The flux sensitivities are calculated globally but only those north of $50^{\circ} \mathrm{N}$ are used to optimize the fluxes. Sensitivities to surface fluxes outside this domain are generally low; however, we calculate their contribution to the change in mixing ratio at each observation time and location by integrating the product of flux sensitivity and prior fluxes outside the domain, following Thompson and Stohl (2014). This is in addition to the contribution from mixing ratios at the termination points of the virtual particles, i.e. 10 days before the observation was made (the definition of these initial mixing ratios is discussed in Sect. 2.5). 
(a)

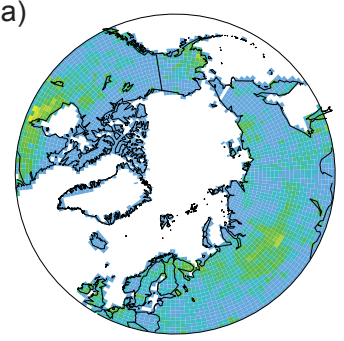

(b)

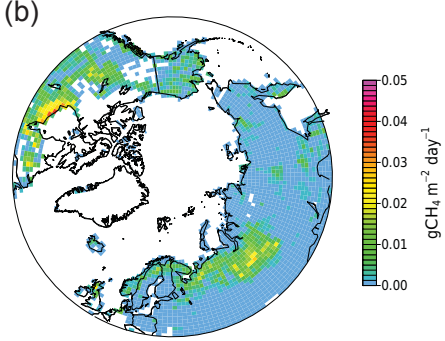

Figure 3. Wetland emissions estimates (units $\mathrm{g} \mathrm{CH}_{4} \mathrm{~m}^{-2}$ day ${ }^{-1}$ ) from LPX-Bern (a) and LPJ-DGVM (b).

\subsection{Initial and background mixing ratios}

Since the Lagrangian simulations only account for changes in mixing ratios due to fluxes up to 10 days before an observation was made, we need to provide an estimate for the contribution prior to that, i.e. the background mixing ratio. The background mixing ratios were calculated by coupling FLEXPART to initial mixing ratio fields according to the method of Thompson and Stohl (2014). Initial mixing ratio fields were calculated for the global troposphere, at monthly temporal and $10^{\circ}$ longitude by $5^{\circ}$ latitude spatial resolution, using a bivariate interpolation of flask-air samples in the NOAA network (Fig. 4a). We used flask-air samples with approximately weekly frequency from 98 sites globally (note that none of the sites used to determine the initial mixing ratios were used in the inversion). Before being used in the interpolation, the time series from each site was filtered for short-lived signals (of less than 1 week) using a local regression method (Ruckstuhl et al., 2012) and gaps of more than 1 month were filled using a four-harmonic plus second-order polynomial function fitted to the whole time series. For the lower and mid-stratosphere, we used mixing ratio fields from the TM5 model (Bergamaschi et al., 2015).

The contribution of the initial mixing ratios to the mixing ratio at a given observation time and location, i.e. the background mixing ratio, was calculated using the 3-hourly FLEXPART back-trajectories. The background mixing ratio is equal to the weighted average of the initial mixing ratios in the grid cells where the back-trajectories terminated 10 days prior to the observation. Figure $4 \mathrm{~b}$ shows an example of the sensitivity to the initial mixing ratios calculated for the site IGR for January 2009. The background mixing ratio at each site is shown in the Supplement Fig. S1.

\subsection{Data selection and observation uncertainties}

Many of the sites used in the inversion are located in the interior of a continent and at high latitude. At such locations, low wind speeds and strong surface-based temperature inversions can occur in winter. Under these conditions, $\mathrm{CH}_{4}$ from local sources can accumulate in shallow layers and atmospheric mixing ratios are extremely difficult to model, as they
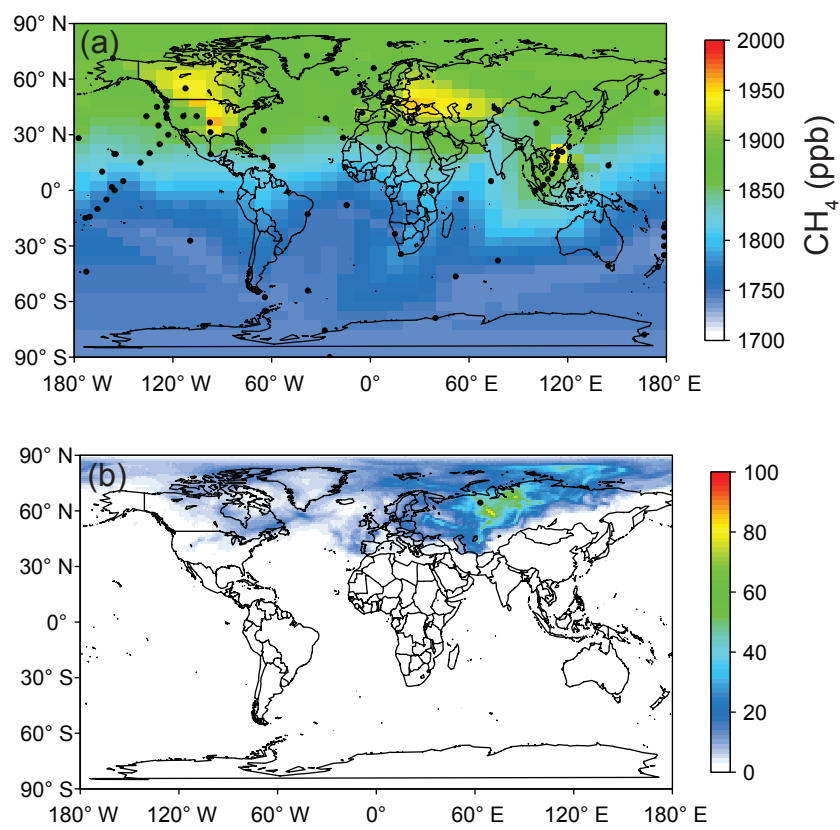

Figure 4. Example of the initial concentration field (units ppb) for January 2009 interpolated from observations in the NOAA network (sites indicated by the black points) (a) and an example shown for site IGR (black dot) of the sensitivity to the initial concentrations (percentage) after 10 days backward calculation (mean January 2009) (b).

are very sensitive to errors in the planetary boundary layer (PBL) height and PBL mixing. To examine the impact of the shallow PBL on the simulated mixing ratios, we performed a test in FLEXPART in which the condition of a minimum PBL height of $100 \mathrm{~m}$ was removed (see Fig. 5). Interestingly, the simulations with no set minimum PBL height were very similar to those with a minimum of $100 \mathrm{~m}$, indicating that the PBL height based on the meteorological reanalyses is greater than $100 \mathrm{~m}$ most of the time.

As the model representation errors for observations made during these very cold periods are very large and not normally distributed, we have applied data selection criteria to avoid assimilating these observations in the inversion. At all sites in the JR-STATION network, temperature is measured at two heights, with the lower level between 11 and $45 \mathrm{ma}$ a.g.l. and the upper between 43 and $85 \mathrm{ma}$ a.g.l., and wind speed is measured at one height. We filtered observations for times when the vertical temperature gradient from the lower to upper level was positive, i.e. the upper level was warmer by at least $1^{\circ} \mathrm{C}$, indicating atmospheric inversion conditions, and when the wind speed was below $3 \mathrm{~m} \mathrm{~s}^{-1}$ (see Fig. 5). By applying these selection criteria, periods when very large positive excursions (of several hundred ppb) were observed, but not captured by the model, were removed. For other continental sites outside the JR-STATION network the temperature was not available at two heights so this crite- 

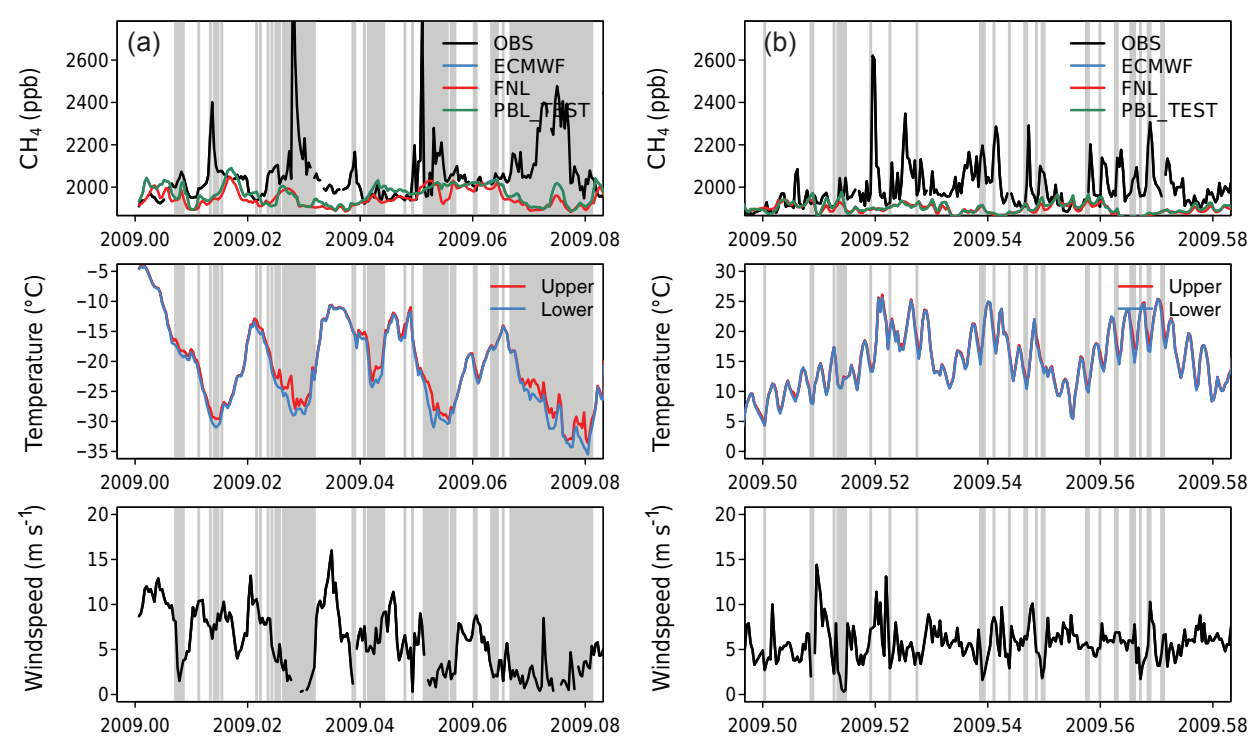

Figure 5. Example of measurements of $\mathrm{CH}_{4}$, temperature at two heights on the tower, and wind speed, at IGR in January 2009 (a) and July 2009 (b). Also shown in the upper plots, are $\mathrm{CH}_{4}$ concentrations simulated with prior fluxes using FLEXPART driven with ECMWF EI (blue) and NCEP FNL (red) meteorological analyses and a sensitivity test using ECMWF EI but with no minimum PBL height set in FLEXPART (green) (note that this is on top of the blue line). The vertical shading indicates periods when data were filtered out.

rion could not be used. However, the estimated model representation errors are likely much smaller at these sites (see Supplement Fig. S1). In the case of ZOT, this is due to the height of the air intake, at $301 \mathrm{~m}$ a.g.l., compared to only 43 to $85 \mathrm{~m}$ a.g.l. in the JR-STATION network, while PAL is located on a hill (565 $\mathrm{m}$ a.s.1.), and both sites are remote from towns or industry. The continental sites in the EC network, FSD, CDL, LLB, and ETL, are also remote from major towns or industry. At the JR-STATION site, IGR, the model representation errors are likely the largest of all sites owing to the relatively low intake height of $47 \mathrm{~m}$ a.g.l. and its location in a small town, meaning that there are emissions in its near field, which cannot be resolved in the model.

Uncertainties in the observation space included estimates for the uncertainty in the measurements and model representation. For the measurement uncertainty, we used a conservative estimate of $5 \mathrm{ppb}$, which is larger than the precision stated by the data providers to account for variations in the instrumental performance. For the model representation uncertainty we included estimates of the transport uncertainty for the transport within the inversion domain and for the background mixing ratios. These estimates were based on differences between FLEXPART simulations made using different meteorological reanalysis data, i.e. ECMWF EI versus NCEP FNL. Since it is computationally demanding to run all FLEXPART calculations twice, we only ran simulations with the two meteorological datasets for 2009 and calculated the mean daytime (12:00 to 16:00) errors for each site and month. This proxy can be considered a lower bound for the true transport uncertainties but provides an indication of the magnitude and spatiotemporal variability of these uncertain- ties. We estimated uncertainties for the transport within the domain of 2 to $65 \mathrm{ppb}$ and for background mixing ratios of 2 to $22 \mathrm{ppb}$. The uncertainty is larger for continental sites and in the winter months as expected due to the challenges of representing the shallow PBL (see Supplement Figs. S1 and S2). In addition to the transport uncertainties, we included an estimate of the temporal representation uncertainty that arises due to the averaging of observations to a daytime mean. This last uncertainty was estimated simply as one standard deviation of the daytime observations. The total uncertainty in the observation space was calculated as the square root of the quadratic sum of the measurement uncertainty and the three model representation uncertainties. We used the square of the observation uncertainty for the diagonal elements of the observation error covariance matrix and assumed the offdiagonal elements to be zero, i.e. that there is no error correlation between observations. As we use mean daytime observations, this assumption is reasonable.

\section{Results}

\subsection{Comparison of simulated and observed mixing ratios}

We start with the comparison of the simulated and observed $\mathrm{CH}_{4}$ mixing ratios - specifically, the comparison between simulations using different prior flux estimates. Figure 6 shows Taylor diagrams of the Pearson correlation coefficient and normalized standard deviation (NSD) for scenarios using the two different prior estimates, i.e. S1 and S2, at each site. 

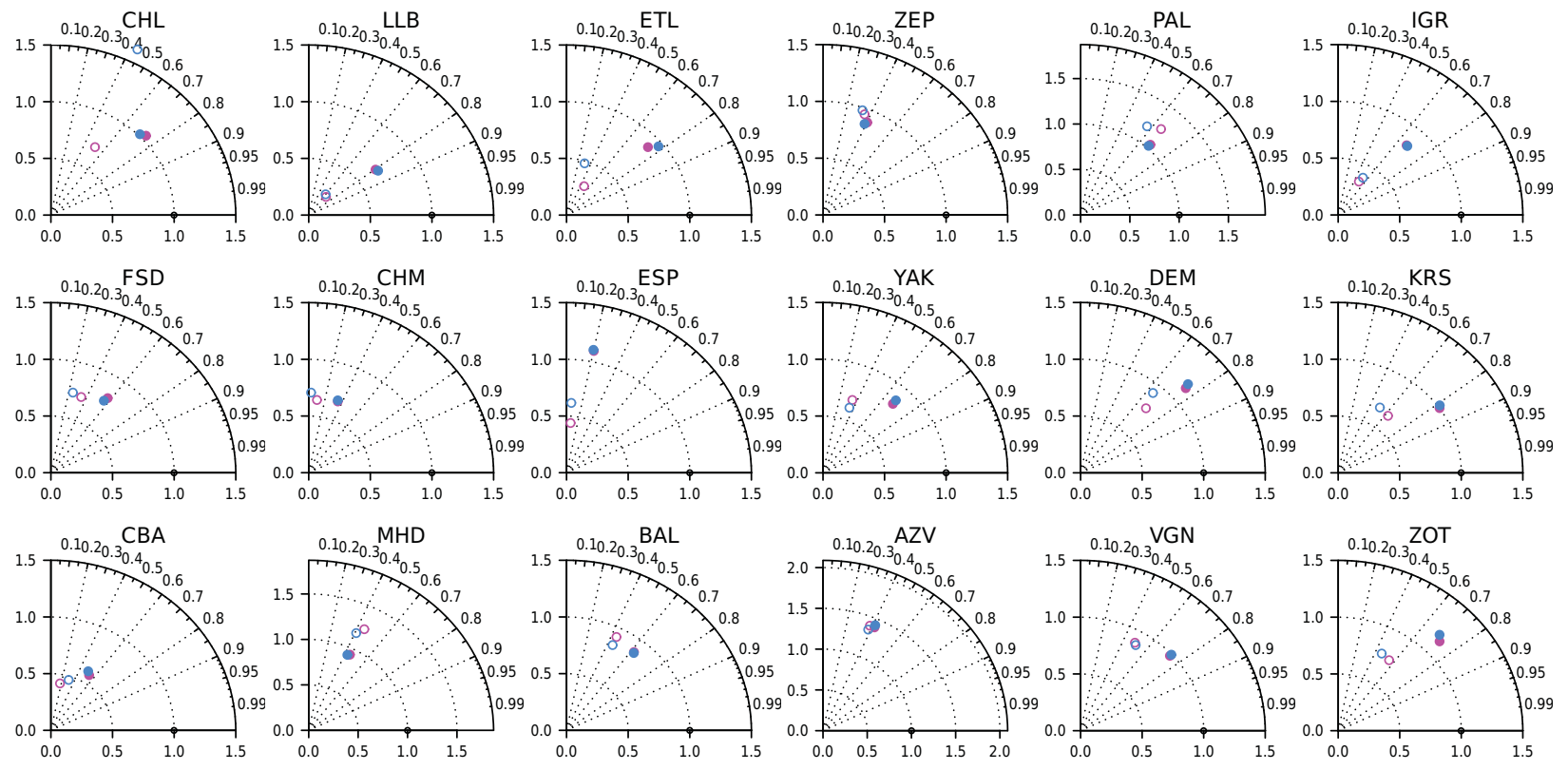

Figure 6. Taylor diagrams for the comparison of the prior (open circles) and posterior (solid circles) simulated concentrations with the observations for 2009 (the radius indicates the normalized standard deviation and the angle the correlation coefficient). The results for the two scenarios are shown (i.e. S1 in magenta and S2 in blue).

It is noteworthy that the mixing ratios modelled using the two different prior flux estimates are distinguishable at most sites, indicating that the observations at these sites are sensitive to small differences in fluxes in the domain. The correlation, a priori, is mostly higher than 0.3 except at the sites CHM and ESP, which have quite low variability and sensitivity to fluxes in the domain (see Supplement, Table S2 and Fig. S1b). In general, the NSD for both prior flux estimates is significantly less than one, indicating that the variability in the mixing ratios is underestimated. It is to some extent expected that NSD is underestimated owing to the limited spatiotemporal resolution of the fluxes; however, it is especially apparent for continental sites, e.g. LLB, ETL, IGR, KRS, YAK, and ZOT. Supplement Fig. S1 shows that the prior fluxes not only underestimate the variability at these sites but also that the prior mixing ratios have a low bias. Overall, the prior flux estimate in S2 (which includes the LPJ-DGVM wetland emissions) gives a slightly closer fit to the observations as seen from the lower cost (see Supplement Table S1).

A posteriori, the simulated mixing ratios from inversion scenarios S1 and S2 are almost indistinguishable and the difference in the cost between these inversions is small. Furthermore, the mixing ratio simulated with the posterior fluxes matches the observations significantly better than a priori, as expected, and the posterior observation-model mismatches are nearly normally distributed and mostly fall within the assumed uncertainty range of the observations (see Supplement Fig. S3). The comparison of the fit to the observations a posteriori is not a sufficient indicator of the inversion performance as the closeness of the fit a posteriori depends on the weighting given to the observation-model and priorposterior flux mismatches (see Eq. 1). A better indicator of the inversion performance is the comparison of the posterior simulated concentrations with observations that were not included in the inversion, i.e. independent observations; however, there is a trade-off between including all observations and leaving some out for an independent comparison. Figure 7 shows the comparison of the prior and posterior simulations from scenario $\mathrm{S} 1$ with observations from regular aircraft profiles at Poker Flats (PFA; 65.1 $1^{\circ} \mathrm{N}, 147.3^{\circ} \mathrm{W}$ ), Estevan Point (ESP; $49.4^{\circ} \mathrm{N}, 126.5^{\circ} \mathrm{W}$ ), and East Trout Lake $\left(\mathrm{ETL} ; 54.3^{\circ}, 105^{\circ} \mathrm{W}\right)$. The comparison was made for three altitude levels, from 4 to $10 \mathrm{~km}, 1$ to $4 \mathrm{~km}$, and 0 to $1 \mathrm{~km}$. Ground-based measurements at ESP and ETL were included in the inversion, therefore the aircraft data at the lower level are not completely independent. Most notable is that the prior fluxes result in a low bias compared to observations at ETL throughout the inversion period, which is visible up to $\sim 4 \mathrm{~km}$ (Fig. 7a). Using the posterior fluxes, this bias is reduced and the correlation increased from 0.33, a priori, to 0.37 , a posteriori (Fig. 7b). At the other independent sites, PFA and ESP, there is only a modest improvement a posteriori versus a priori because these sites are less sensitive to the fluxes in the domain; ESP is a coastal site and PFA is not in an area where there are significant fluxes. 

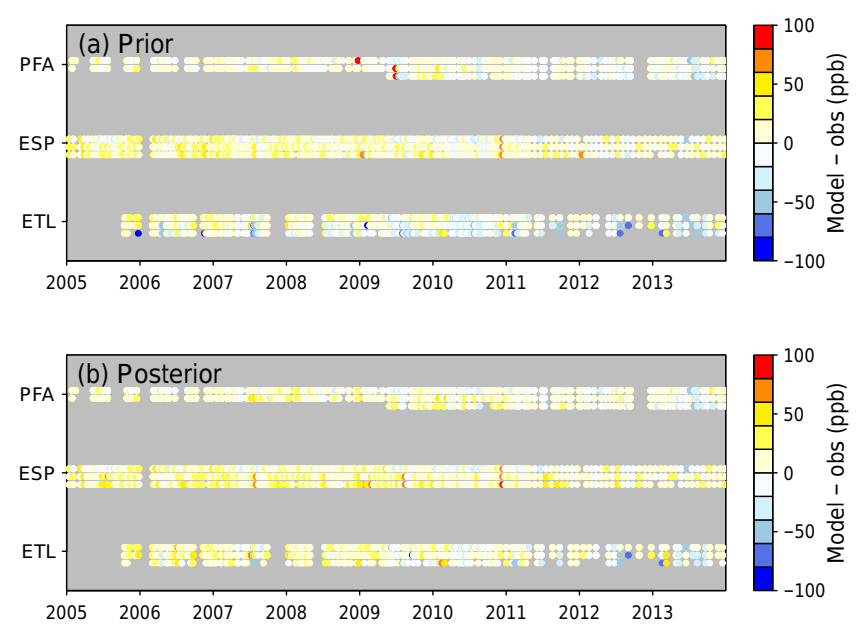

Figure 7. Comparison of simulated concentrations from scenario S1 with independent observations from NOAA aircraft campaigns at Poker Flats (PFA), Estevan Point (ESP), and East Trout Lake (ETL) in Canada. The three rows of dots from top to bottom are the comparison for the mean of data between 4 and $10 \mathrm{~km}, 1$ and $4 \mathrm{~km}$, and 0 and $1 \mathrm{~km}$. Prior concentrations (a) and posterior concentrations (b).

\subsection{Comparison of the posterior fluxes from different scenarios}

In addition to the inversion scenarios $\mathrm{S} 1$ and $\mathrm{S} 2$, using different prior flux estimates, we included a scenario, S3, to test for the impact of the changing observation network with time. Scenario S3 uses the same prior fluxes as S1 but includes only sites with quasi-continuous records over the period of inversion (see Table 1 and Supplement Fig. S4). Figure 8 shows the annual mean posterior fluxes, as well as the posterior-prior flux differences, obtained for scenarios S1, S2, and S3 (note we show only the result for 2009 as the other years were analogous). For all three scenarios, the posterior flux distribution is very similar with the largest fluxes in the vicinity of the Western Siberian Lowlands (WSL), Europe, western Canada, and around the Hudson Bay Lowlands (HBL). In addition, there are a number of hot spots, notably in eastern Europe and Russia, which are anthropogenic emissions present in the EDGAR inventory and are largely unaltered by the inversions. The distribution of the flux increments (i.e. the posterior-prior flux difference) is also similar across the three scenarios. This is not unexpected for $\mathrm{S} 1$ and $\mathrm{S} 3$ (Fig. 8b and f) as they use the same prior estimates, but it is noteworthy that $\mathrm{S} 2$ shows the same pattern of positive increments in the WSL and eastern Canada and negative increments in Europe and western Russia. One difference in S2 compared to S1 and S3 though, is the negative increment in the HBL area, which results from the higher prior estimate of the LPJ-DGVM model for wetland fluxes in this region (S1 and S3, which use the LPX-Bern wetland fluxes, show almost no change for the HBL area).
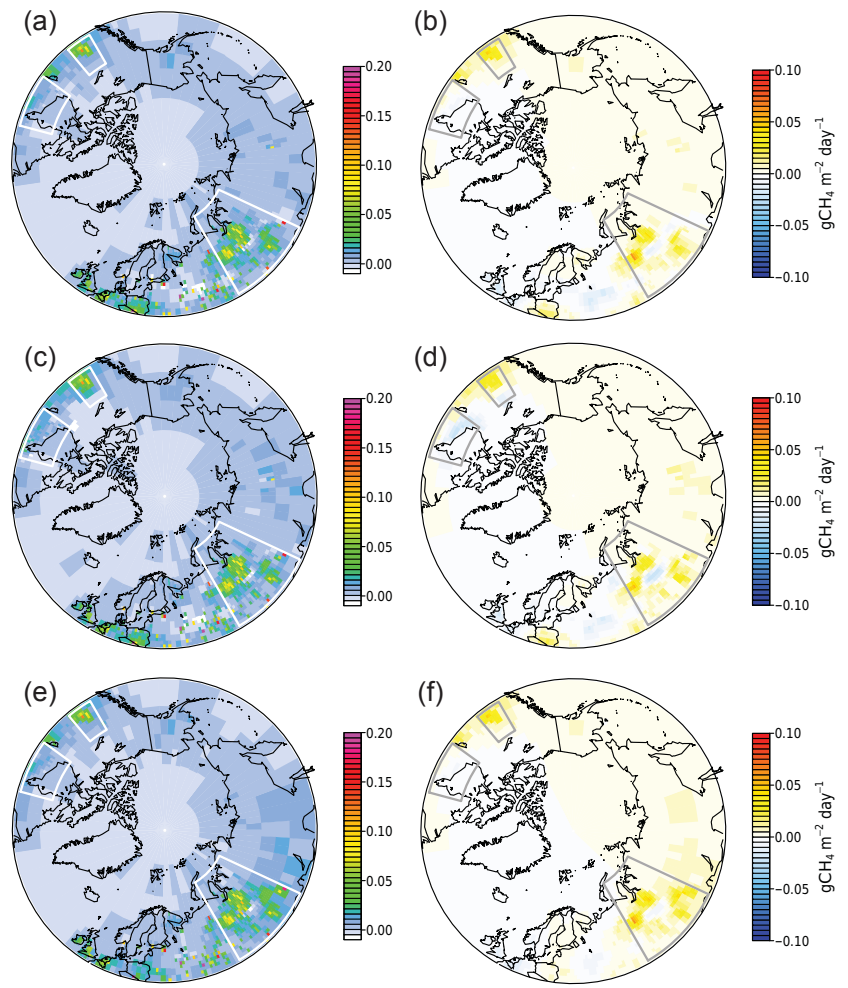

Figure 8. Annual mean posterior fluxes of $\mathrm{CH}_{4}$ shown for 2009 for scenario S1 (a), the difference between the posterior and prior fluxes for S1 (b); the posterior fluxes for scenario S2 (c) and the difference for S2 (d); and the posterior fluxes for scenario S3 (e) and the difference for S3 (f). The bordered areas are Alberta in western Canada, the Hudson Bay lowlands (HBL) in eastern Canada, and the western Siberian lowlands (WSL) (units are $\mathrm{g} \mathrm{CH}_{4} \mathrm{~m}^{-2} \mathrm{day}^{-1}$ ).
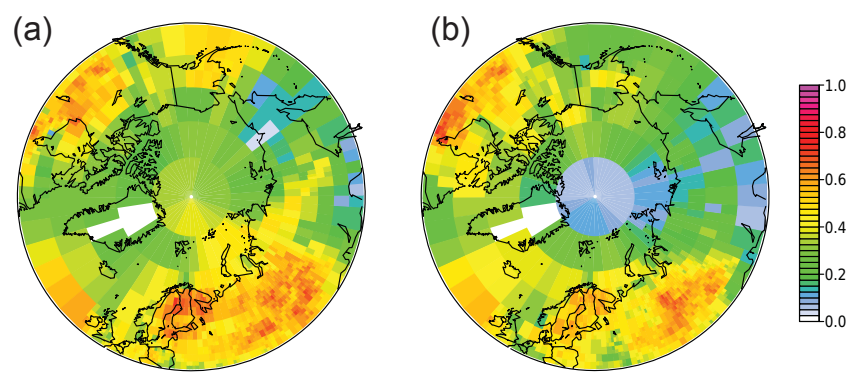

Figure 9. Fractional uncertainty reduction for 2009 for scenarios S1 and S2 (a), and S3 (b).

Figure 9 shows the uncertainty reduction for scenarios S1 and $\mathrm{S} 3$ calculated as $1-\sigma_{\text {post }} / \sigma_{\text {prior }}$ where $\sigma$ is the uncertainty in each grid cell. Since S2 uses the same observations and prior uncertainty estimates as $\mathrm{S} 1$, the uncertainty reduction is equal to that of S1 and is, therefore, not shown. Scenarios S1 and S2 include 19 sites and a total of 3291 observations in 2009, compared to 12 sites and 2499 observations in S3. The impact of the additional sites of YAK, VGN, AZV, and ZOT in S1 and S2 can be seen in the greater uncertainty 
Table 3. Mean prior and posterior flux totals (units $\mathrm{Tg} \mathrm{yr}^{-1}$ ) for each inversion scenario and comparison to independent inversion estimates for 2005 to 2010 (the overlapping period).

\begin{tabular}{|c|c|c|c|c|c|}
\hline \multirow[t]{2}{*}{ Inversion } & \multirow[t]{2}{*}{$\begin{array}{l}\text { No. in situ }+ \\
\quad \text { (flask) sites }\end{array}$} & \multicolumn{2}{|c|}{ North America } & \multicolumn{2}{|c|}{ Northern Eurasia } \\
\hline & & Prior & Posterior & Prior & Posterior \\
\hline S1 & $17+(5)$ & $9.5 \pm 5.1$ & $16.6 \pm 1.1$ & $44.4 \pm 12.5$ & $55.2 \pm 2.5$ \\
\hline $\mathrm{S} 2$ & $17+(5)$ & $14.2 \pm 5.1$ & $17.9 \pm 1.1$ & $43.3 \pm 12.5$ & $52.2 \pm 2.5$ \\
\hline S3 & $10+(2)$ & $9.5 \pm 5.1$ & $17.1 \pm 1.3$ & $44.4 \pm 12.5$ & $59.5 \pm 3.2$ \\
\hline MACC NOAA $^{a}$ & (7) & - & 14.0 & - & 34.0 \\
\hline $\mathrm{CT}-\mathrm{CH}_{4}^{\mathrm{b}}$ & $6+(10)$ & 7.5 & 8.1 & 60.3 & 49.7 \\
\hline
\end{tabular}

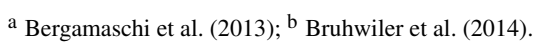

reduction in Siberia, and that of the site CHL, in Canada. In all scenarios, however, the uncertainty reduction is greatest in Europe, western Siberia, and Canada but modest in eastern Siberia, Greenland, and Alaska.

Figure 10 shows the area-integrated fluxes for northern North America (Canada and Alaska) and northern Eurasia (Europe and Russia) from the three scenarios. For North America, there is a clear difference between the prior fluxes in the phase of the seasonal cycle and the summer maximum, which is due to the different models used for wetlands (i.e. LPX-Bern versus LPJ-DGVM). In contrast, there is no significant difference between the posterior fluxes from scenarios S1 to S3, indicating first, that the seasonal cycle is well constrained in the inversion, and second, that the discontinuity of observations from the sites CHL and CHM has little impact on the northern North American integrated fluxes. For northern Eurasia, there are again differences in the prior fluxes, owing to the choice of land surface model, which are no longer visible in the posterior fluxes. While the results from scenarios S1 and S2 are very similar, S3 results in higher summer maxima from 2008 onwards. This is due to the exclusion of data from four sites (YAK, VGN, AZV, and ZOT) in S3, which means the inversion is more dependent on the remaining observations at IGR, DEM, and KRS for constraining fluxes in Siberia. A corollary of this is that since only these sites are available up to 2007, the posterior fluxes may be overestimated for 2005 to 2007 also in scenarios S1 and S2. The temporal variability and, in particular, the seasonality, of the fluxes is discussed in more detail in Sect. 4.2.

\section{Discussion}

High-latitude $\left(>50^{\circ} \mathrm{N}\right) \mathrm{CH}_{4}$ emissions are largely from anthropogenic sources (particularly oil and gas exploitation), $\sim 60 \%$, and natural wetlands, $\sim 40 \%$, according to the prior estimates used in this study. The different sources are not always spatially distinct at the resolution of the emission sensitivities (in this study $1^{\circ} \times 1^{\circ}$ ). In this case, it is not possible to resolve them without the use of additional atmospheric tracers, such as changes in the ${ }^{13} \mathrm{C}$ to ${ }^{12} \mathrm{C}$ isotope ratio in $\mathrm{CH}_{4}$ (written as $\delta^{13} \mathrm{C}$ ), which is sensitive to the emission source (e.g. Dlugokencky et al., 2011). Currently observations of $\delta^{13} \mathrm{C}$ are much scarcer than for $\mathrm{CH}_{4}$ mixing ratios and we have not included these in our inversion. Therefore, we focus the discussion mainly on the distribution of the total $\mathrm{CH}_{4}$ source.

We present regional emission totals giving the range of scenarios S1 and S2, which are better constrained than S3 as they include all available observations. The range is generally close to the uncertainty calculated for each scenario and which is given in Table 3. We, however, include S3 in the analysis of the inter-annual variability and trends, as this scenario uses only observations from sites that are available for most of the inversion period, thus year-to-year differences are independent of changes in the observation coverage.

\subsection{Spatial distribution of the fluxes}

\subsubsection{North America}

For northern North America $\left(>50^{\circ} \mathrm{N}\right)$, we estimate a mean total source of 16.6 to $17.9 \mathrm{Tg} \mathrm{yr}^{-1}$ for $2005-2010$ (the period overlapping with independent global inversion studies), which is 7.1 and $3.7 \mathrm{Tg} \mathrm{yr}^{-1}$ higher than the prior estimates in scenarios S1 and S2 (which included wetland flux estimates from LPX-Bern and LPJ-DGVM, respectively). Our estimate is also substantially higher than the global inversion estimates of Carbon-Tracker $\mathrm{CH}_{4}$, of $8.1 \mathrm{Tg} \mathrm{yr}^{-1}$ (Bruhwiler et al., 2014), and TM5, of $14.0 \mathrm{Tg} \mathrm{yr}^{-1}$ (Bergamaschi et al., 2013) (see Table 3). However, it is lower than the regional inversion estimate of Miller et al. (2014) for Canada, of $21.3 \pm 1.6 \mathrm{Tg} \mathrm{yr}^{-1}$ for $2007-2008$. The regions dominating northern North American $\mathrm{CH}_{4}$ fluxes, and where we see differences from the prior estimates, are the HBL and western Canada.

Methane fluxes in the HBL $\left(50-60^{\circ} \mathrm{N}, 75-96^{\circ} \mathrm{W}\right)$ are largely dominated by wetlands, more than $90 \%$ of the total according to the prior estimates (see Fig. 3). For 
the HBL, the posterior fluxes from scenarios $\mathrm{S} 1$ and $\mathrm{S} 2$ are 2.7 to $3.4 \mathrm{Tg} \mathrm{yr}^{-1}$ and are close to the prior estimate of $\mathrm{S} 1\left(2.7 \mathrm{Tg} \mathrm{yr}^{-1}\right)$ and to the inversion estimates of Miller et al. (2014) $\left(2.4 \pm 0.32 \mathrm{Tg} \mathrm{yr}^{-1}\right)$, Bruhwiler et al. (2014) (2.7 $\left.\mathrm{Tg} \mathrm{yr}^{-1}\right)$, and Pickett-Heaps et al. (2011) $\left(2.3 \pm 0.3 \mathrm{Tg} \mathrm{yr}^{-1}\right)$. However, our posterior fluxes are significantly lower (by 1.0 to $1.7 \mathrm{Tg} \mathrm{yr}^{-1}$ ) than the prior estimate of $\mathrm{S} 2$, which included wetland fluxes from LPJ-DGVM. Land surface models vary greatly in the estimate for HBL wetland emissions, from 2.2 to $11.3 \mathrm{Tg} \mathrm{yr}^{-1}$, due at least partly to the definition of wetland extent (Melton et al., 2013). The large discrepancy in LPJ-DGVM could be due to an oversimplified calculation of water table depth, for which soil moisture is used as a proxy. LPX-Bern, in comparison, uses a dynamic calculation of water table depth based on the DYPTOP model.

In western Canada, the main source region approximately corresponds to the province of Alberta (in this study we compare the region $50-60^{\circ} \mathrm{N}, 110-120^{\circ} \mathrm{W}$ ). In the prior flux estimates in scenarios $\mathrm{S} 1$ and $\mathrm{S} 2$, this region has quite low $\mathrm{CH}_{4}$ emissions, 1.6 and $3.0 \mathrm{Tg} \mathrm{yr}^{-1}$, respectively. In contrast, all scenarios find a much larger source a posteriori, of 5.0 to $5.8 \mathrm{Tg} \mathrm{yr}^{-1}$, with most of the increase in the southern part of the province where there are no significant wetlands. Miller et al. (2014) also found large fluxes in Alberta and, similar to their study, we find that these fluxes persist throughout the year (Figs. 11 and 12) unlike fluxes dominated by wetlands, which have a strong seasonal cycle (see the HBL region in Fig. 12), suggesting that they may be of anthropogenic origin. We hypothesize that the emissions are largely from natural gas production since Alberta produces $72 \%$ of Canada's natural gas and has Canada's largest shale gas reserves (https://www.neb-one.gc.ca/index-eng.html). Assuming that the wintertime wetland emissions are negligible, and that the seasonal variation in anthropogenic emissions is small (which has been found for emissions from oil and gas operations in North America; Smith et al., 2015), we use the wintertime emissions as an estimate for the anthropogenic source. Our estimate of $4.3 \pm 1.3 \mathrm{Tg} \mathrm{yr}^{-1}$ is approximately 3 times larger than that of EDGAR and, for comparison, approximately 8 times larger than the estimate of the GAINS model (Höglund-Isaksson, 2012), suggesting that anthropogenic sources in Alberta are currently strongly underestimated in at least these two inventories.

\subsubsection{Northern Eurasia}

For northern Eurasia, we estimate mean total emissions of 52.5 to $55.5 \mathrm{Tg} \mathrm{yr}^{-1}$ (scenarios S1 and S2) for 2005-2010, which is 8.9 to $10.8 \mathrm{Tg} \mathrm{yr}^{-1}$ higher than the prior estimates. Our estimates are close to that found by the Carbon-Tracker $\mathrm{CH}_{4}$ inversion of $49.7 \mathrm{Tg} \mathrm{yr}^{-1}$ (Bruhwiler et al., 2014) but much larger than those found by the TM5 inversions of approximately 34.0 $\mathrm{Tg} \mathrm{yr}^{-1}$ (Bergamaschi et al., 2013) (see Table 3 ). One reason for the low estimate from the inversion
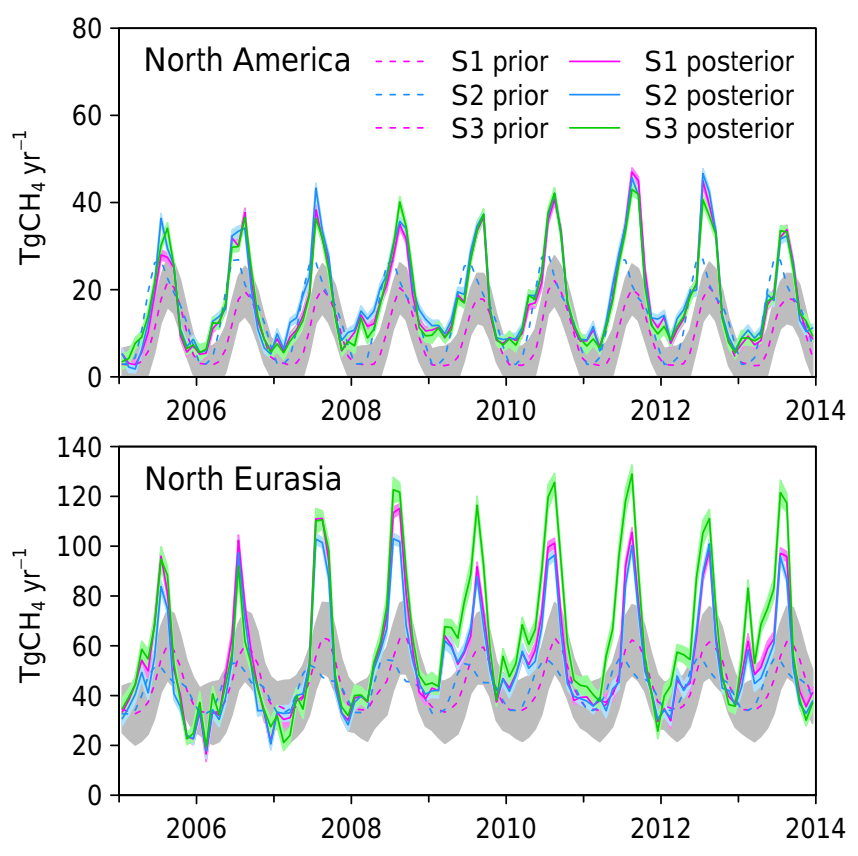

Figure 10. Area-integrated $\mathrm{CH}_{4}$ fluxes (units $\mathrm{Tg} \mathrm{CH}_{4} \mathrm{yr}^{-1}$ ) from the three scenarios shown monthly for northern North America and northern Eurasia. The prior fluxes are shown by the dashed lines and the posterior fluxes by the solid lines (note that the prior fluxes used in scenarios S1 and S3 are the same). The grey shading indicates the prior uncertainty (shown only for the $\mathrm{S} 1$ prior) and the coloured shading indicates the posterior uncertainty.

of Bergamaschi et al. (2013) could be the poor observational constraint for the high northern latitudes; the inversion included only seven sites north of $50^{\circ} \mathrm{N}$, all of which have flask-air samples at only approximately weekly intervals, and none of the sites were located in Siberia. Also, their global inversion that included SCIAMACHY observations did not contain any satellite observations north of $50^{\circ} \mathrm{N}$.

The main increase in the posterior fluxes, relative to both priors, is in the WSL region $\left(50-75^{\circ} \mathrm{N}, 60-95^{\circ} \mathrm{E}\right)$. A posteriori, we estimate a source of 19.3 to $19.9 \mathrm{Tg} \mathrm{yr}^{-1}$, which is 7.1 to $8.9 \mathrm{Tg} \mathrm{yr}^{-1}$ higher than the prior estimates in scenarios $\mathrm{S} 1$ and $\mathrm{S} 2$, respectively. Our posterior estimates, however, fall in the mid-range of a recent study, which gave a tolerance interval of 5 to $28 \mathrm{Tg} \mathrm{yr}^{-1}$ for the total source in 2010 based on a regional inversion (Berchet et al., 2015). Wetlands cover $25 \%$ of the land surface in the WSL and are an important source of $\mathrm{CH}_{4}$ in this region (Bohn et al., 2015). In addition, there is extensive oil and gas production in the WSL, which is also a significant source of $\mathrm{CH}_{4}$ and complicates the attribution of emissions from inversions to anthropogenic versus natural sources. Averaging the mean monthly emissions (from scenarios S1 and S2) for December to February, we estimate an anthropogenic source of $12.7 \pm 3.6 \mathrm{Tg} \mathrm{yr}^{-1}$ or, equivalently, $\sim 65 \%$ of the annual total. From the residual, we estimate a wetland source of $6.9 \pm 3.6 \mathrm{Tg} \mathrm{yr}^{-1}$, assuming 

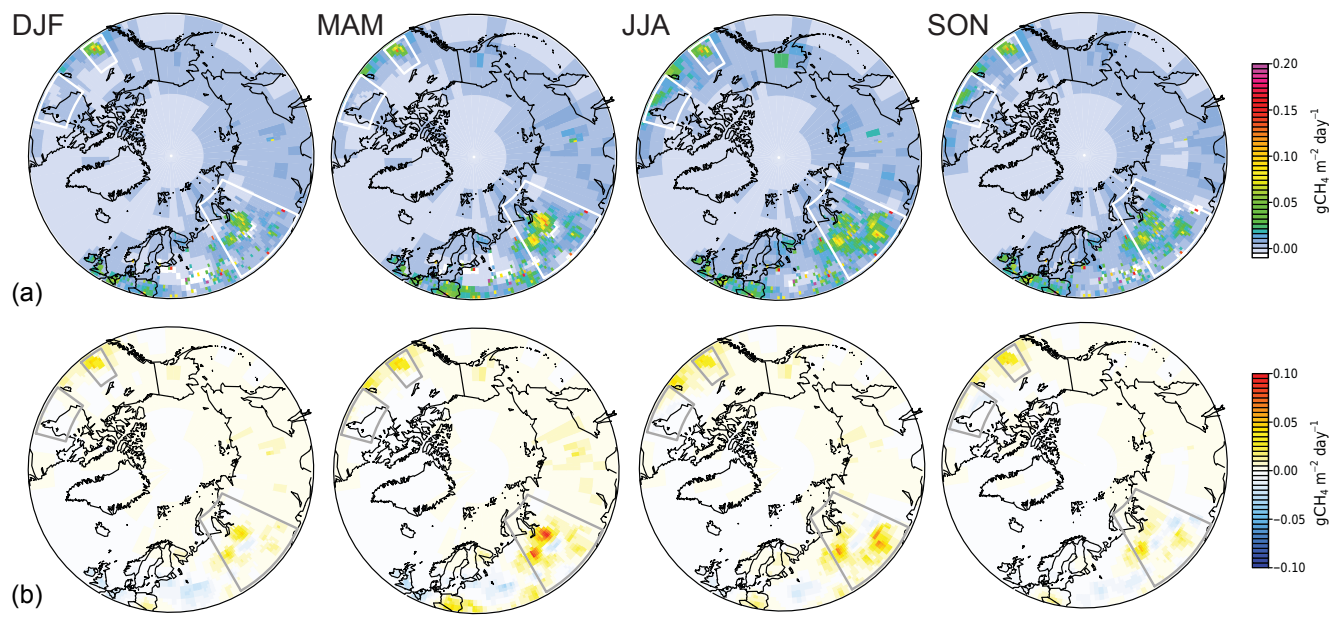

Figure 11. Mean posterior fluxes of $\mathrm{CH}_{4}$ (a) and posterior-prior differences (b) shown for scenario $\mathrm{S} 1$ for winter 2008-2009 (DJF), spring 2009 (MAM), summer 2009 (JJA), and autumn 2009 (SON). (Units are $\mathrm{g} \mathrm{CH}_{4} \mathrm{~m}^{-2} \mathrm{day}^{-1}$ ).

that the summer wild fire emissions are very small, which, based on the prior estimate of GFED-3.1 of $\sim 0.08 \mathrm{Tg} \mathrm{yr}^{-1}$, is reasonable. We note, however, that anthropogenic sources in WSL may have some seasonal variation and that this would also affect the wetland source estimate. One such seasonally dependent source could be, for example, gas flaring, which has been suggested to have higher $\mathrm{CH}_{4}$ emissions in low temperatures owing to problems of igniting the flare. Our estimate of the wetland source is higher than the prior values from LPX-Bern and LPJ-DGVM of 4.9 and $5.9 \mathrm{Tg} \mathrm{yr}^{-1}$, respectively, but falls in the mid-range of estimates from Berchet et al. (2015) (1 to $13 \mathrm{Tg} \mathrm{yr}^{-1}$ ) and is close to the mean of inversion estimates used in the inter-comparison study of Bohn et al. (2015) $\left(6.1 \pm 1.2 \mathrm{Tg} \mathrm{yr}^{-1}\right)$. On the other hand, it is lower than the estimate of Bruhwiler et al. (2014) of $10.3 \mathrm{Tg} \mathrm{yr}^{-1}$. Our anthropogenic flux estimate is higher than that from EDGAR $\left(6.8 \mathrm{Tg} \mathrm{yr}^{-1}\right)$ and the inversion of Bruhwiler et al. (2014) $\left(8.1 \mathrm{Tg} \mathrm{yr}^{-1}\right)$ but in the mid-range of estimates from Berchet et al. (2015) (6 to $\left.16 \mathrm{Tg} \mathrm{yr}^{-1}\right)$ and lower than that of GAINS $\left(19 \mathrm{Tg} \mathrm{yr}^{-1}\right)$.

Large fluxes of $\mathrm{CH}_{4}$ from the ocean to the atmosphere have been reported for the East Siberian Arctic Shelf (ESAS) with a source estimated to total $17 \mathrm{Tg} \mathrm{yr}^{-1}$ representing $\sim 3 \%$ of the global source to the atmosphere (Shakhova et al., 2010, 2015). Although our inversion has only a modest reduction in uncertainty in the ESAS region (see Fig. 9) we do not find any evidence of a large source in this region. This is consistent with a recent study based on atmospheric observations and inverse modelling, which found the ESAS region to be a source of only 0.5 to $4.5 \mathrm{Tg} \mathrm{yr}^{-1}$ (Berchet et al., 2016).

\subsection{Temporal variability of the fluxes}

\subsubsection{Seasonal cycle}

Emissions in the HBL region are dominated by wetlands. For this region, our inversion indicates a gradual increase in emissions in spring reaching a maximum in August to September, which is considerably later compared to the LPJDGVM model, but close to the LPX-Bern model (Fig. 12). The poorer representation of the seasonal cycle in LPJDGVM may be because this model overemphasizes the control of temperature on $\mathrm{CH}_{4}$ production in the high latitudes (Bergamaschi et al., 2007). In autumn (September to October), the inversion indicates a more rapid decline in emissions compared to both models, and close to zero emissions from November to March. A similar pattern is seen for all of northern North America, suggesting that the wetland emissions are dominating the seasonality also at this scale. Although the annual emission is largely dominated by fluxes during the growing season (Whalen et al., 1992), a few studies have indicated high fluxes during spring and fall due to thaw and freeze dynamics (Mastepanov et al., 2008; Zona et al., 2016). This process is also parameterized in the LPXBern model. Our inversion results, however, do not indicate any large-scale emissions in the HBL outside the growing season.

In the WSL region the maximum occurs in July to August, and is earlier than that of LPX-Bern in August and later than that of LPJ-DGVM in June. The maximum in July-August is consistent with the majority of land surface models in the inter-comparison study of Bohn et al. (2015). Similarly to the HBL, LPJ-DGVM produces a too-early onset for the spring increase in emissions, again this may be due to an oversensitivity to temperature, and both models have a more gradual decline in emissions in autumn compared to the inversion re- 

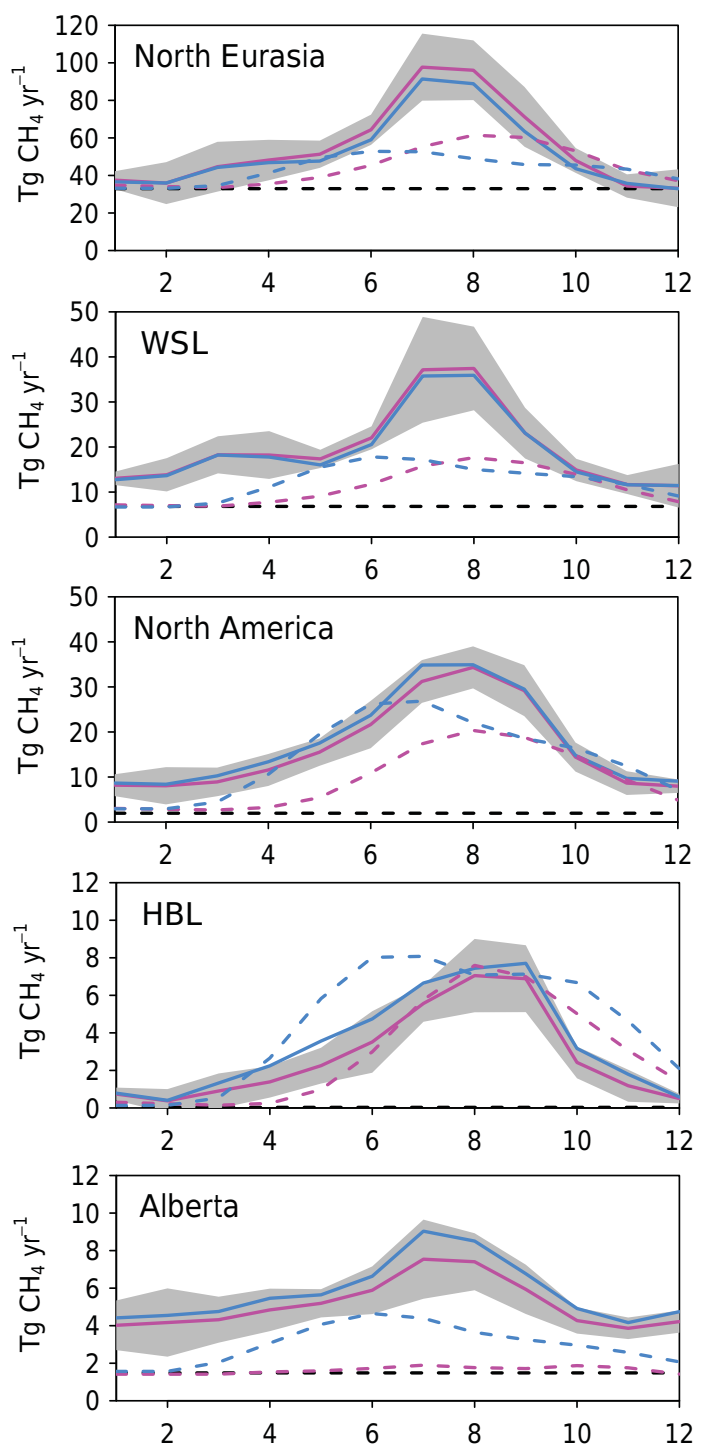

Figure 12. Mean seasonal cycles (2005-2013) of the integrated $\mathrm{CH}_{4}$ flux for different regions (units $\mathrm{Tg} \mathrm{yr}^{-1}$ ). The grey shading indicates the standard deviation of the monthly fluxes. The solid lines show the posterior fluxes and the dashed lines show the prior fluxes. Magenta is for scenario S1 (including wetland fluxes from LPXBern), blue is for S2 (including wetland fluxes from LPJ-DGVM), and black (dashed) is for prior anthropogenic fluxes.

sults. In contrast to the HBL, there are substantial emissions in winter, which are predominantly due to anthropogenic sources (Umezawa et al., 2012). Another notable feature is the small secondary peak in March. Berchet et al. (2015) also detected a March peak in 2010 and suggested that this may be due to anthropogenic emissions, in particular from higher gas production during the late winter. We explored an alternative explanation for the spring peak, that is, wetland emissions during spring thaw, which have been previously observed in high latitudes from flux chamber and eddy covariance measurements (Tokida et al., 2007; Hargreaves et

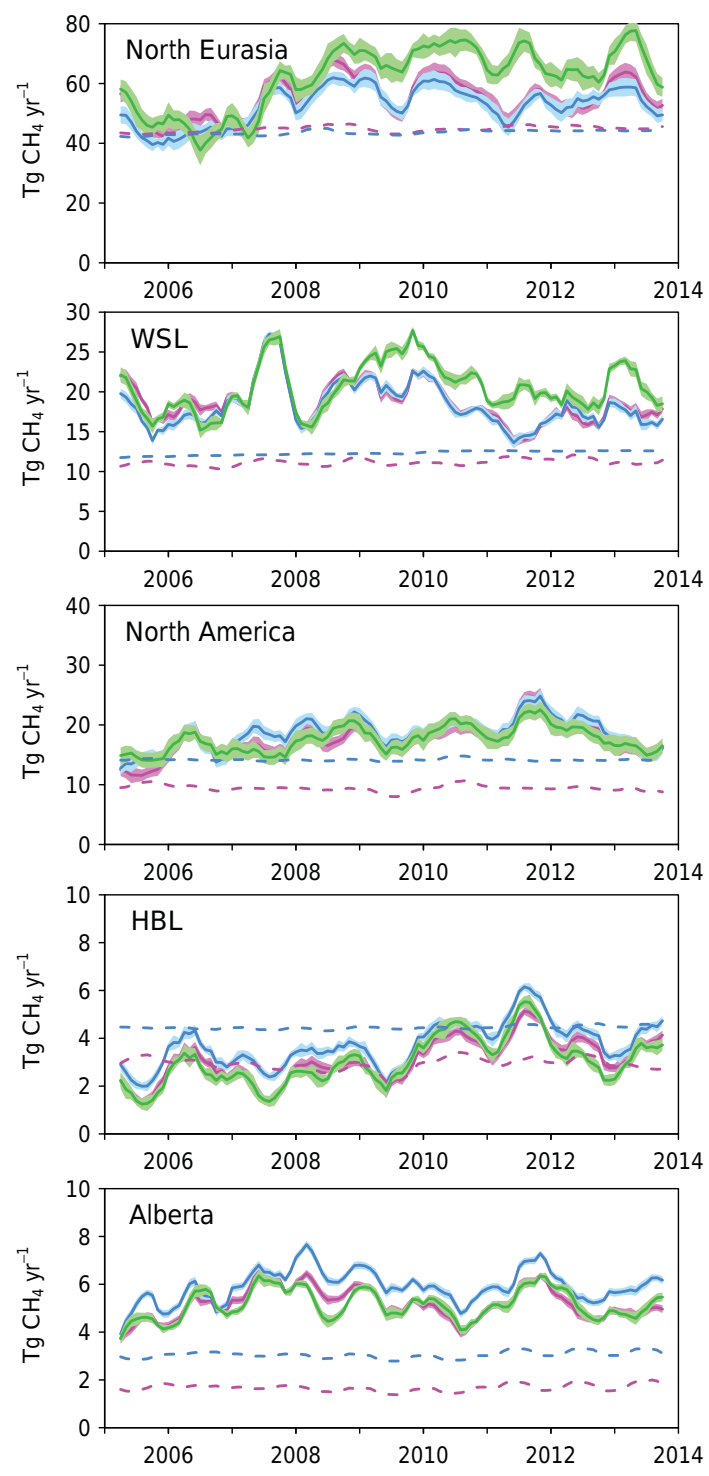

Figure 13. Inter-annual variability in $\mathrm{CH}_{4}$ fluxes (units $\mathrm{Tg} \mathrm{yr}^{-1}$ ) for northern Eurasia, WSL, northern North America, HBL and Alberta. The inter-annual variability was calculated by subtracting the mean seasonal cycle (resolved monthly) from the time series for each region and performing a running average on the residuals with a 6month time window. The solid lines are the posterior fluxes from S1 (magenta), S2 (blue), and S3 (green); the dashed lines are the prior fluxes from S1 and S2. The shading indicates the posterior uncertainty.

al., 2001; Mastepanov et al., 2013). Such emissions occur as snow melts and the surface soil begins to thaw, allowing $\mathrm{CH}_{4}$ that has been trapped below the surface during the winter, and which was formed by methanogenesis before the subsurface soil froze, to escape to the atmosphere. We examined air temperature measured at the three JR-STATION sites in northern WSL (IGR, DEM and NOY); the temperature is minimum in January to February and zero or above zero temperatures are 
only reached in March. We did not, however, find any consistent pattern between year-to-year spring temperature variation and the occurrence of a spring peak. To determine the cause of the spring peak in emissions, further information is required, such as measurements of atmospheric $\delta^{13} \mathrm{C}-\mathrm{CH}_{4}$.

\subsubsection{Inter-annual variability}

The inter-annual variability was calculated by first subtracting the mean seasonal cycle (resolved monthly) from the time series for each region, and second, by performing a running average on the residuals with a 6-month time window (see Fig. 13). In northern Eurasia, the year-to-year variability in the posterior fluxes is considerable and is much larger than that in the prior fluxes. In 2005 to 2006, and 2011, the fluxes fell below the 10th percentile, while in 2007, 2008, 2010, and 2013, the fluxes reached or exceeded the 90th percentile. The inter-annual variability in the WSL is similar to that of all of northern Eurasia $(R=0.53)$ and, in particular, the 2007 anomaly almost entirely originates in the WSL. The year 2007 was particularly warm in the WSL $\left(+1.1{ }^{\circ} \mathrm{C}\right.$ compared to the 2005-2013 annual mean from ECMWF EI data) and particularly wet $\left(+0.87 \times 10^{-2} \mathrm{~m}^{3} \mathrm{~m}^{-3}\right.$ soil water volume). Therefore, it is likely that this anomaly is driven by increased $\mathrm{CH}_{4}$ production by wetlands. We find an anomaly for the WSL in 2007 of +3.3 Tg of $\mathrm{CH}_{4}$ (compared to the 20052013 annual mean), which is similar to that found by Bousquet et al. (2011) of +4 to $+5 \mathrm{Tg}$ for the boreal region. This finding further supports the hypothesis that the 2007 anomaly in the atmospheric growth rate was at least in part due to an increase in boreal wetland emissions as previously suggested (Rigby et al., 2008; Dlugokencky et al., 2009; Bousquet et al., 2011; Bruhwiler et al., 2014).

Although warmer temperature was a factor in the 2007 anomaly in the WSL, there is no significant correlation of temperature with $\mathrm{CH}_{4}$ flux over 2005-2013, since positive temperature anomalies often coincided with negative soil moisture anomalies, which limit $\mathrm{CH}_{4}$ production. In general for WSL, we find a weak correlation of $\mathrm{CH}_{4}$ flux with soil moisture $(R=0.33, p$ value $=<0.001$; see Supplement Fig. S5), and that the correlation increases with a 6-month lag $\left(R=0.66, p\right.$ value $\left.=<1 \times 10^{-12}\right)$, suggesting that wintertime soil moisture may be important for the annual $\mathrm{CH}_{4}$ production.

In North America, again considerable year-to-year variability in the posterior fluxes is seen and exceeds that of the prior. The years 2005 and 2013 had negative anomalies, while 2011 stood out as a strong positive anomaly. The time series for the HBL is strongly correlated with that of North America $(R=0.80)$, while that of Alberta was moderately correlated $(R=0.59)$. The year 2011 was a warm year in boreal North America $\left(+0.26^{\circ} \mathrm{C}\right.$ compared to the 20052013 annual mean). For the HBL, we find a moderate correlation with soil temperature $\left(R=0.53, p\right.$ value $\left.=<1 \times 10^{-8}\right)$ but a negative correlation with soil moisture (which arises as temperature and moisture are negatively correlated in the HBL) indicating that soil moisture is not limiting $\mathrm{CH}_{4}$ production. This result contrasts with the result for the WSL, where soil moisture does appear to be a limiting factor. In addition, we looked for correlations between $\mathrm{CH}_{4}$ flux and snow depth and precipitation (from ECMWF EI) but found these to be generally not significant (see Supplement Fig. S5).

\subsubsection{Analysis of flux trends}

Mann-Kendall tests showed significant trends over 20052013 in northern North America $(p$ value $<0.01)$ with a mean rate of increase of 0.38 to $0.57 \mathrm{Tg} \mathrm{yr}^{-2}$ (range of all scenarios), and specifically in the HBL, with mean rate of increase of 0.22 to $0.23 \mathrm{Tg} \mathrm{yr}^{-2}$ ( $p$ value $\ll 0.001$ ). However, we find no significant trend for Alberta. ECMWF EI data show increasing soil temperature over northern North America $\left(0.08^{\circ} \mathrm{C} \mathrm{yr}^{-1}\right)$ and, especially, the $\operatorname{HBL}\left(0.13^{\circ} \mathrm{C} \mathrm{yr}^{-1}\right)$, which suggests that the increase in $\mathrm{CH}_{4}$ fluxes is due to wetlands.

Similarly, we find a significant trend ( $p$ value $<0.01$ ) in northern Eurasia with mean of 0.76 to $2.50 \mathrm{Tg} \mathrm{yr}^{-2}$. The upper limit of this range is from S3, which was less well constrained for this region; without S3 the upper limit is $1.09 \mathrm{Tg} \mathrm{yr}^{-2}$, which we consider more plausible, thus we consider only scenarios S1 and S2 in the following discussion. The northern Eurasian trend has approximately equal contributions from northern Europe (north of $50^{\circ} \mathrm{N}$ ) and Russia of 0.53 to $0.57 \mathrm{Tg} \mathrm{yr}^{-2}$ and 0.30 to $0.72 \mathrm{Tg} \mathrm{yr}^{-2}$, respectively. The result for northern Europe contrasts with the prior fluxes, which show a small decrease owing to a reduction in the anthropogenic emissions of $-0.07 \mathrm{Tg} \mathrm{yr}^{-2}$ (according to EDGAR-4.2FT2010). Instead, the increase found in the inversions may be due to wetland sources, a hypothesis that is supported by ECMWF EI data, which show an increase in soil moisture $\left(0.07 \times 10^{-2} \mathrm{~m}^{3} \mathrm{~m}^{-3} \mathrm{yr}^{-1}\right)$. For Russia, on the other hand, the prior fluxes show a substantial increase of $0.30 \mathrm{Tg} \mathrm{yr}^{-2}$ due to anthropogenic sources and this corresponds to our lower estimate from the inversions. Further support for an increase in anthropogenic sources is given by British Petroleum energy statistics, which show steady increases in oil and gas production in Russia between 2005 and 2013 of 4 and $12 \%$, respectively, while over the same time period, there is no trend in the ECMWF EI soil moisture or temperature.

In contrast to our study, previous multi-annual inversions have not detected any trend in the high-northern-latitude $\mathrm{CH}_{4}$ fluxes (Bruhwiler et al., 2014; Bergamaschi et al., 2013). This may be owing to the limited number of observation sites included (see Sect. 4.1.2). The study of Bloom et al. (2010), conversely, predicted an increase in extra-tropical $\left(45-67^{\circ} \mathrm{N}\right)$ and Arctic $\left(>67^{\circ} \mathrm{N}\right)$ wetland fluxes from 2003 to 2007 (the period covered by their study), which was based on a positive correlation of $\mathrm{CH}_{4}$ production and temperature. 
Table 4. Summary showing the range of the prior and posterior estimates from scenarios $\mathrm{S} 1$ and $\mathrm{S} 2$ for the mean fluxes (Tg yr ${ }^{-1}$ ) for

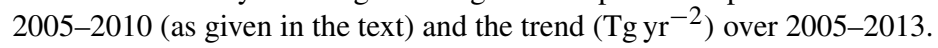

\begin{tabular}{lrrrrr}
\hline & North America & HBL & Alberta & Northern Eurasia & WSL \\
\hline Prior fluxes & $9.5-14.2$ & $2.7-4.4$ & $1.6-3.0$ & $43.3-44.4$ & $11.0-12.2$ \\
Posterior fluxes & $16.6-17.9$ & $2.7-3.4$ & $5.0-5.8$ & $52.5-55.5$ & $19.3-19.9$ \\
Trend & $0.38-0.57$ & $0.22-0.23$ & 0 & $0.76-1.09$ & 0 \\
\hline
\end{tabular}

\section{Summary and conclusions}

We have presented spatiotemporally resolved $\mathrm{CH}_{4}$ flux estimates for the high northern latitudes (north of $50^{\circ} \mathrm{N}$ ) from an atmospheric inversion for the period 2005 to 2013 . The inversion included observations from in situ measurement sites in the JR-STATION network in Siberia, the EC network in Canada, as well as the sites, Pallas in Finland, Zeppelin in Svalbard, Mace Head in Ireland, and ZOTTO in Siberia, and four discrete flask-air sampling sites. This is the first time that these observations have been used together in an atmospheric inversion. We find a $\mathrm{CH}_{4}$ source from the high northern latitudes of 82.0 to $83.6 \mathrm{Tg} \mathrm{yr}^{-1}$ (the range of $\mathrm{S} 1$ and $\mathrm{S} 2$ ) representing $\sim 15 \%$ of the global total (i.e. $548 \mathrm{Tg} \mathrm{yr}^{-1}$ from recent global inversions, Kirschke et al., 2013). This is significantly higher than the prior estimates of 64.3 to $67.9 \mathrm{Tg} \mathrm{yr}^{-1}$ ( $12 \%$ of the global total).

For northern North America, we find an annual mean total source of 16.6 to $17.9 \mathrm{Tg} \mathrm{yr}^{-1}$ (Table 4) which is larger than the prior estimates based on EDGAR-4.2FT2010, for anthropogenic emissions, and the land surface models LPXBern and LPJ-DGVM, for the wetland fluxes. The regions of the HBL and Alberta were found to be dominating the source. In the HBL, the fluxes are mainly from wetlands and our estimate of 2.7 to $3.4 \mathrm{Tg} \mathrm{yr}^{-1}$ is close to the prior estimate in scenario S1 (which included wetland flux estimates from LPX-Bern) and to other inversion estimates, but lower than the prior estimate in S2 (which included wetland flux estimates from LPJ-DGVM). The seasonal cycle in the HBL showed a maximum in August to September, with a rapid decline in fluxes thereafter and near-zero fluxes from November to March. In Alberta, our inversions reveal an important source of 5.0 to $5.8 \mathrm{Tg} \mathrm{yr}^{-1}$, which was found to persist even during winter suggesting that it is of anthropogenic origin in which case, current inventories significantly underestimate the emissions.

For northern Eurasia, we find an annual mean total source of 52.2 to $55.5 \mathrm{Tg} \mathrm{yr}^{-1}$. This is significantly larger than the prior estimates, predominantly due to an increase in fluxes in the WSL, from 11.0 to $12.2 \mathrm{Tg} \mathrm{yr}^{-1}$, a priori, to 19.3 to $19.9 \mathrm{Tg} \mathrm{yr}^{-1}$, a posteriori. For the WSL, we estimate an anthropogenic source of $12.7 \pm 3.6 \mathrm{Tg} \mathrm{yr}^{-1}$ and a wetland source of $6.9 \pm 3.6 \mathrm{Tg} \mathrm{yr}^{-1}$. Anthropogenic emissions in the WSL are dominated by gas and oil production, and our estimate is significantly larger than that of the EDGAR-
4.2FT2010 inventory but lower than that of the GAINS model. The seasonal cycle in the WSL has a maximum in July to August, consistent with most land surface models, and shows considerable emissions in winter owing to anthropogenic sources. For Russia, we found an increasing trend in the fluxes of 0.30 to $0.72 \mathrm{Tg} \mathrm{yr}^{-2}$ with the lower end of this range corresponding to the trend in the anthropogenic emissions in the EDGAR-4.2FT2010 inventory. The absence of any trend in soil temperature or moisture over our study period further suggests that the increase is largely due to anthropogenic sources.

Although our study covers only a relatively short period, from 2005 to 2013, notable variations in the year-to-year $\mathrm{CH}_{4}$ fluxes have been identified. In particular, large positive anomalies were seen for the WSL in 2007, and for the HBL in 2011, both due to anomalously high temperatures. Moreover, we detect positive trends in the source from North America, and specifically from the HBL, which are correlated with soil temperature. This result may indicate a positive temperature feedback on $\mathrm{CH}_{4}$ emissions in the high latitudes, as expected in the first order based on the temperature dependence of microbial $\mathrm{CH}_{4}$ production. However, on longer timescales, the impact of higher temperature on hydrology and ecosystems in the boreal and Arctic regions, and thus on $\mathrm{CH}_{4}$ production and oxidation, is very uncertain and an important area of on-going research.

Data availability. The observations of atmospheric $\mathrm{CH}_{4}$ mixing ratio used in this paper are available from the following sources: NOAA ESRL data: http://www.esrl.noaa.gov/gmd/ dv/data/; JR-STATION data: http://db.cger.nies.go.jp/portal/geds/ atmosphericAndOceanicMonitoring; EC and Teriberka data: http: //ds.data.jma.go.jp/gmd/wdcgg/wdegg.html; Zeppelin data: http:// ebas.nilu.no; ZOTTO tower data: on request to J. V. Lavric at ICOS ERIC; Pallas station data: on request to T. Aalto at FMI; and AGAGE data: http://agage.eas.gatech.edu/data_archive/. The inversion framework, FLEXINVERT, is available from http://flexinvert. nilu.no.

\section{The Supplement related to this article is available online at doi:10.5194/acp-17-3553-2017-supplement.}

Competing interests. The authors declare that they have no conflict of interest. 
Acknowledgements. We thank Colm Sweeney and Ed Dlugokencky for use of the NOAA ESRL data, Peter Bergamaschi for providing TM5 inversion results, and Renato Spahni for providing LPX-Bern wetland fluxes. This study was funded by the Nordic Centre of Excellence, eSTICC (eScience Tool for Investigating Climate Change in northern high latitudes), funded by Nordforsk (grant no. 57001) and the projects SLICFONIA (emissions of Short-LIved Climate FOrcers Near and In the Arctic), funded by the NORRUSS programme of the Research Council of Norway (grant no. 233642) and EVA (Earth system modelling of climate Variations in the Anthropocene), funded by the Research Council of Norway (grant no. 229771).

Edited by: P. Jöckel

Reviewed by: two anonymous referees

\section{References}

Aalto, T., Hatakka, J., and Lallo, M.: Tropospheric methane in northern Finland: seasonal variations, transport patterns and correlations with other trace gases, Tellus B, 59, 251-259, doi:10.1111/j.1600-0889.2007.00248.x, 2007.

Alexe, M., Bergamaschi, P., Segers, A., Detmers, R., Butz, A., Hasekamp, O., Guerlet, S., Parker, R., Boesch, H., Frankenberg, C., Scheepmaker, R. A., Dlugokencky, E., Sweeney, C., Wofsy, S. C., and Kort, E. A.: Inverse modelling of $\mathrm{CH}_{4}$ emissions for 2010-2011 using different satellite retrieval products from GOSAT and SCIAMACHY, Atmos. Chem. Phys., 15, 113-133, doi:10.5194/acp-15-113-2015, 2015.

AMAP: Assessment 2015: Methane as an Arctic climate forcer, Arctic Monitoring and Assessment Programme (AMAP), Oslo, Norway, 2015.

Berchet, A., Pison, I., Chevallier, F., Paris, J.-D., Bousquet, P., Bonne, J.-L., Arshinov, M. Y., Belan, B. D., Cressot, C., Davydov, D. K., Dlugokencky, E. J., Fofonov, A. V., Galanin, A., Lavric, J., Machida, T., Parker, R., Sasakawa, M., Spahni, R., Stocker, B. D., and Winderlich, J.: Natural and anthropogenic methane fluxes in Eurasia: a mesoscale quantification by generalized atmospheric inversion, Biogeosciences, 12, 5393-5414, doi:10.5194/bg-12-5393-2015, 2015.

Berchet, A., Bousquet, P., Pison, I., Locatelli, R., Chevallier, F., Paris, J.-D., Dlugokencky, E. J., Laurila, T., Hatakka, J., Viisanen, Y., Worthy, D. E. J., Nisbet, E., Fisher, R., France, J., Lowry, D., Ivakhov, V., and Hermansen, O.: Atmospheric constraints on the methane emissions from the East Siberian Shelf, Atmos. Chem. Phys., 16, 4147-4157, doi:10.5194/acp-16-41472016, 2016.

Bergamaschi, P., Frankenberg, C., Meirink, J. F., Krol, M., Dentener, F., Wagner, T., Platt, U., Kaplan, J. O., Korner, S., Heimann, M., Dlugokencky, E. J., and Goede, A.: Satellite chartography of atmospheric methane from SCIAMACHY on board ENVISAT: 2. Evaluation based on inverse model simulations, J. Geophys. Res.-Atmos., 112, D02304, doi:10.1029/2006JD007268, 2007.

Bergamaschi, P., Houweling, S., Segers, A., Krol, M., Frankenberg, C., Scheepmaker, R. A., Dlugokencky, E., Wofsy, S. C., Kort, E. A., Sweeney, C., Schuck, T., Brenninkmeijer, C., Chen, H., Beck, V., and Gerbig, C.: Atmospheric $\mathrm{CH}_{4}$ in the first decade of the 21st century: Inverse modeling analysis using SCIAMACHY satellite retrievals and NOAA surface measurements, Atmospheric $\mathrm{CH}_{4}$ in the first decade of the 21st century: Inverse modeling analysis using SCIAMACHY satellite retrievals and NOAA surface measurements, J. Geophys. Res.-Atmos., 118, 7350-7369, doi:10.1002/jgrd.50480, 2013.

Bergamaschi, P., Corazza, M., Karstens, U., Athanassiadou, M., Thompson, R. L., Pison, I., Manning, A. J., Bousquet, P., Segers, A., Vermeulen, A. T., Janssens-Maenhout, G., Schmidt, M., Ramonet, M., Meinhardt, F., Aalto, T., Haszpra, L., Moncrieff, J., Popa, M. E., Lowry, D., Steinbacher, M., Jordan, A., O'Doherty, S., Piacentino, S., and Dlugokencky, E.: Top-down estimates of European $\mathrm{CH}_{4}$ and $\mathrm{N}_{2} \mathrm{O}$ emissions based on four different inverse models, Atmos. Chem. Phys., 15, 715-736, doi:10.5194/acp-15-715-2015, 2015.

Bey, I., Jacob, D. J., Logan, J. A., and Yantosca, R. M.: Asian chemical outflow to the Pacific in spring: Origins, pathways, and budgets, J. Geophys. Res., 106, 23073-23095, 2001.

Biastoch, A., Treude, T., Rüpke, L. H., Riebesell, U., Roth, C., Burwicz, E. B., Park, W., Latif, M., Böning, C. W., and Madec, G.: Rising Arctic Ocean temperatures cause gas hydrate destabilization and ocean acidification, Geophys. Res. Lett., 38, L08602, doi:10.1029/2011GL047222, 2011.

Bloom, A. A., Palmer, P. I., Fraser, A., Reay, D. S., and Frankenberg, C.: Large-Scale Controls of Methanogenesis Inferred from Methane and Gravity Spaceborne Data, Science, 327, 322-327, doi:10.1126/science.1175176, 2010.

Bohn, T. J., Lettenmaier, D. P., Sathulur, K., Bowling, L. C., Podest, E., McDonald, K. C., and Friborg, T.: Methane emissions from western Siberian wetlands: heterogeneity and sensitivity to climate change, Environ. Res. Lett., 2, 045015, doi:10.1088/17489326/2/4/045015, 2007.

Bohn, T. J., Melton, J. R., Ito, A., Kleinen, T., Spahni, R., Stocker, B. D., Zhang, B., Zhu, X., Schroeder, R., Glagolev, M. V., Maksyutov, S., Brovkin, V., Chen, G., Denisov, S. N., Eliseev, A. V., Gallego-Sala, A., McDonald, K. C., Rawlins, M. A., Riley, W. J., Subin, Z. M., Tian, H., Zhuang, Q., and Kaplan, J. O.: WETCHIMP-WSL: intercomparison of wetland methane emissions models over West Siberia, Biogeosciences, 12, 3321-3349, doi:10.5194/bg-12-3321-2015, 2015.

Bousquet, P., Ringeval, B., Pison, I., Dlugokencky, E. J., Brunke, E.G., Carouge, C., Chevallier, F., Fortems-Cheiney, A., Frankenberg, C., Hauglustaine, D. A., Krummel, P. B., Langenfelds, R. L., Ramonet, M., Schmidt, M., Steele, L. P., Szopa, S., Yver, C., Viovy, N., and Ciais, P.: Source attribution of the changes in atmospheric methane for 2006-2008, Atmos. Chem. Phys., 11, 3689-3700, doi:10.5194/acp-11-3689-2011, 2011.

Bridgham, S. D., Cadillo-Quiroz, H., Keller, J. K., and Zhuang, Q.: Methane emissions from wetlands: biogeochemical, microbial, and modeling perspectives from local to global scales, Glob. Change Biol., 19, 1325-1346, doi:10.1111/gcb.12131, 2013.

Bruhwiler, L., Dlugokencky, E., Masarie, K., Ishizawa, M., Andrews, A., Miller, J., Sweeney, C., Tans, P., and Worthy, D.: CarbonTracker- $\mathrm{CH}_{4}$ : an assimilation system for estimating emissions of atmospheric methane, Atmos. Chem. Phys., 14, 82698293, doi:10.5194/acp-14-8269-2014, 2014.

Cao, M., Gregson, K., and Marshall, S.: Global methane emission from wetlands and its sensitivity to climate change, Atmos. 
Environ., 32, 3293-3299, doi:10.1016/S1352-2310(98)00105-8, 1998.

Chevallier, F., Fisher, M., Peylin, P., Serrar, S., Bousquet, P., Bréon, F. M., Chédin, A., and Ciais, P.: Inferring $\mathrm{CO}_{2}$ sources and sinks from satellite observations: Method and application to TOVS data, J. Geophys. Res., 110, D24309, doi:10.1029/2005jd006390, 2005.

Christensen, T. R., Prentice, I. C., Kaplan, J., Haxeltine, A., and Sitch, S.: Methane flux from northern wetlands and tundra, Tellus B, 48, 652-661, doi:10.1034/j.1600-0889.1996.t01-4-00004.x, 1996.

Christensen, T. R., Ekberg, A., Ström, L., Mastepanov, M., Panikov, N., Öquist, M., Svensson, B. H., Nykänen, H., Martikainen, P. J., and Oskarsson, H.: Factors controlling large scale variations in methane emissions from wetlands, Geophys. Res. Lett., 30, 1414, doi:10.1029/2002GL016848, 2003.

Chylek, P., Folland, C. K., Lesins, G., Dubey, M. K., and Wang, M.: Arctic air temperature change amplification and the Atlantic Multidecadal Oscillation, Geophys. Res. Lett, 36, L14801, doi:10.1029/2009g1038777, 2009.

Dlugokencky, E. J., Bruhwiler, L., White, J. W. C., Emmons, L. K., Novelli, P. C., Montzka, S. A., Masarie, K. A., Lang, P. M., Crotwell, A. M., Miller, J. B., and Gatti, L. V.: Observational constraints on recent increases in the atmosperic $\mathrm{CH}_{4}$ burden, Geophys. Res. Lett, 36, L18803, doi:10.1029/2009g1039780, 2009.

Dlugokencky, E. J., Nisbet, E. G., Fisher, R., and Lowry, D.: Global atmospheric methane: budget, changes and dangers, Philos. T. Roy. Soc. A, 369, 2058-2072, doi:10.1098/rsta.2010.0341, 2011.

Dlugokencky, E., Lang, P., Crotwell, A., Masarie, K., and Crotwell, M.: Atmospheric Methane Dry Air Mole Fractions from the NOAA ESRL Carbon Cycle Cooperative Global Air Sampling Network, 1983-2014, Version: 2015-08-03, available at: ftp: //aftp.cmdl.noaa.gov/data/trace_gases/ch4/flask/surface/ (last access: 7 March 2017), 2015.

Enting, I. G.: Inverse Problems in Atmospheric Constituent Transport, Cambridge University Press, Cambridge, New York, 2002.

Etheridge, D. M., Steele, L., Francey, R. J., and Langenfelds, R. L.: Atmospheric methane between $1000 \mathrm{AD}$ and present: Evidence of anthropogenic emissions and climatic variability, J. Geophys. Res.-Atmos., 103, 15979-15993, doi:10.1029/98JD00923, 1998.

Hargreaves, K. J., Fowler, D., Pitcairn, C. E. R., and Aurela, M.: Annual methane emission from Finnish mires estimated from eddy covariance campaign measurements, Theor. Appl. Climatol., 70, 203-213, 2001.

Hayhoe, K., Kheshgi, H. S., Jain, A. K., and Wuebbles, D. J.: Substitution of natural gas for coal: climatic effects of utility sector emissions, Climatic Change, 54, 107-139, doi:10.1023/A:1015737505552, 2002.

Houweling, S., Kaminski, T., Dentener, F., Lelieveld, J., and Heimann, M.: Inverse modeling of methane sources and sinks using the adjoint of a global transport model, J. Geophys. Res.Atmos., 104, 26137-26160, doi:10.1029/1999jd900428, 1999.

Houweling, S., Krol, M., Bergamaschi, P., Frankenberg, C., Dlugokencky, E. J., Morino, I., Notholt, J., Sherlock, V., Wunch, D., Beck, V., Gerbig, C., Chen, H., Kort, E. A., Röckmann, T., and Aben, I.: A multi-year methane inversion using SCIAMACHY, accounting for systematic errors using TCCON measurements, Atmos. Chem. Phys., 14, 3991-4012, doi:10.5194/acp-14-39912014, 2014.
Höglund-Isaksson, L.: Global anthropogenic methane emissions 2005-2030: technical mitigation potentials and costs, Atmos. Chem. Phys., 12, 9079-9096, doi:10.5194/acp-12-9079-2012, 2012.

Kirschke, S., Bousquet, P., Ciais, P., Saunois, M., Canadell, J. G., Dlugokencky, E. J., Bergamaschi, P., Bergmann, D., Blake, D. R., Bruhwiler, L., Cameron-Smith, P., Castaldi, S., Chevallier, F., Feng, L., Fraser, A., Heimann, M., Hodson, E. L., Houweling, S., Josse, B., Fraser, P. J., Krummel, P. B., Lamarque, J. -F., Langenfelds, R. L., Le Quere, C., Naik, V., O'Doherty, S., Palmer, P. I., Pison, I., Plummer, D., Poulter, B., Prinn, R. G., Rigby, M., Ringeval, B., Santini, M., Schmidt, M., Shindell, D. T., Simpson, I. J., Spahni, R., Steele, L. P., Strode, S. A., Sudo, K., Szopa, S., van der Werf, G. R., Voulgarakis, A., van Weele, M., Weiss, R. F., Williams, J. E., and Zeng, G.: Three decades of global methane sources and sinks, Nat. Geosci., 6, 813-823, doi:10.1038/ngeo1955, 2013.

Lambert, G. and Schmidt, S.: Reevaluation of the oceanic flux of methane: Uncertainties and long term variations, Chemosphere, 26, 579-589, doi:10.1016/0045-6535(93)90443-9, 1993.

Lehner, B. and Döll, P.: Development and validation of a global database of lakes, reservoirs and wetlands, J. Hydrol., 296, 1-22, doi:10.1016/j.jhydrol.2004.03.028, 2004.

Mastepanov, M., Sigsgaard, C., Dlugokencky, E. J., Houweling, S., Ström, L., Tamstorf, M. P., and Christensen, T. R.: Large tundra methane burst during onset of freezing, Nature, 456, 628-630, doi:10.1038/nature07464, 2008.

Mastepanov, M., Sigsgaard, C., Tagesson, T., Ström, L., Tamstorf, M. P., Lund, M., and Christensen, T. R.: Revisiting factors controlling methane emissions from high-Arctic tundra, Biogeosciences, 10, 5139-5158, doi:10.5194/bg-10-5139-2013, 2013.

Matthews, E., Fung, I., and Lerner, J.: Methane emission from rice cultivation: Geographic and seasonal distribution of cultivated areas and emissions, Global Biogeochem. Cy., 5, 3-24, doi:10.1029/90GB02311, 1991.

Melton, J. R., Wania, R., Hodson, E. L., Poulter, B., Ringeval, B., Spahni, R., Bohn, T., Avis, C. A., Beerling, D. J., Chen, G., Eliseev, A. V., Denisov, S. N., Hopcroft, P. O., Lettenmaier, D. P., Riley, W. J., Singarayer, J. S., Subin, Z. M., Tian, H., Zürcher, S., Brovkin, V., van Bodegom, P. M., Kleinen, T., Yu, Z. C., and Kaplan, J. O.: Present state of global wetland extent and wetland methane modelling: conclusions from a model intercomparison project (WETCHIMP), Biogeosciences, 10, 753788, doi:10.5194/bg-10-753-2013, 2013.

Miller, S. M., Worthy, D. E., Michalak, A. M., Wofsy, S. C., Kort, E. A., Havice, T. C., Andrews, A. E., Dlugokencky, E. J., Kaplan, J. O., and Levi, P. J.: Observational constraints on the distribution, seasonality, and environmental predictors of North American boreal methane emissions, Global Biogeochem. Cy., 28, 146-160, doi:10.1002/2013GB004580, 2014.

Miller, S. M., Commane, R., Melton, J. R., Andrews, A. E., Benmergui, J., Dlugokencky, E. J., Janssens-Maenhout, G., Michalak, A. M., Sweeney, C., and Worthy, D. E. J.: Evaluation of wetland methane emissions across North America using atmospheric data and inverse modeling, Biogeosciences, 13, 13291339, doi:10.5194/bg-13-1329-2016, 2016.

Monteil, G., Houweling, S., Butz, A., Guerlet, S., Schepers, D., Hasekamp, O., Frankenberg, C., Scheepmaker, R., Aben, I., and Röckmann, T.: Comparison of $\mathrm{CH}_{4}$ inversions based on 15 
months of GOSAT and SCIAMACHY observations, J. Geophys. Res.-Atmos., 118, 11-807, doi:10.1002/2013JD019760, 2013.

Nisbet, E. G., Dlugokencky, E. J., and Bousquet, P.: Methane on the Rise - Again, Science, 343, 493-495, doi:10.1126/science.1247828, 2014.

Nisbet, E. G., Dlugokencky, E. J., Manning, M. R., Lowry, D., Fisher, R. E., France, J. L., Michel, S. E., Miller, J. B., White, J. W. C., Vaughn, B., Bousquet, P., Pyle, J. A., Warwick, N. J., Cain, M., Brownlow, R., Zazzeri, G., Lanoisellé, M., Manning, A. C., Gloor, E., Worthy, D. E. J., Brunke, E., Labuschagne, C., Wolff, E. W., and Ganesan, A. L.: Rising atmospheric methane: 2007-2014 growth and isotopic shift, Global Biogeochem. Cy., 30, 1-15, doi:10.1002/2016GB005406, 2016.

Pickett-Heaps, C. A., Jacob, D. J., Wecht, K. J., Kort, E. A., Wofsy, S. C., Diskin, G. S., Worthy, D. E. J., Kaplan, J. O., Bey, I., and Drevet, J.: Magnitude and seasonality of wetland methane emissions from the Hudson Bay Lowlands (Canada), Atmos. Chem. Phys., 11, 3773-3779, doi:10.5194/acp-11-3773-2011, 2011.

Ridgwell, A. J., Marshall, S. J., and Gregson, K.: Consumption of atmospheric methane by soils: A process-based model, Global Biogeochem. Cy., 13, 59-70, doi:10.1029/1998gb900004, 1999.

Rigby, M., Prinn, R. G., Fraser, P. J., Simmonds, P. G., Langenfelds, R. L., Huang, J., Cunnold, D. M., Steele, L. P., Krummel, P. B., Weiss, R. F., O'Doherty, S., Salameh, P. K., Wang, H. J., Harth, C. M., Mühle, J., and Porter, L. W.: Renewed growth of atmospheric methane, Geophys. Res. Lett., 35, L22805, doi:10.1029/2008g1036037, 2008.

Ruckstuhl, A. F., Henne, S., Reimann, S., Steinbacher, M., Vollmer, M. K., O’Doherty, S., Buchmann, B., and Hueglin, C.: Robust extraction of baseline signal of atmospheric trace species using local regression, Atmos. Meas. Tech., 5, 2613-2624, doi:10.5194/amt-5-2613-2012, 2012.

Sanderson, M. G.: Biomass of termites and their emissions of methane and carbon dioxide: A global database, Global Biogeochem. Cy., 10, 543-557, doi:10.1029/96gb01893, 1996.

Sasakawa, M., Shimoyama, K., Machida, T., Tsuda, N., Suto, H., Arshinov, M., Davydov, D., Fofonov, A., Krasnov, O., and Saeki, T.: Continuous measurements of methane from a tower network over Siberia, Tellus B, 62, 403-416, doi:10.1111/j.16000889.2010.00494.x, 2010.

Schaefer, H., Fletcher, S. E., Veidt, C., Lassey, K. R., Brailsford, G. W., Bromley, T. M., Dlugokencky, E. J., Michel, S. E., Miller, J. B., Levin, I., Lowe, D. C., Martin, R. J., Vaughn, B. H., and White, J. W.: A 21st century shift from fossil-fuel to biogenic methane emissions indicated by $13 \mathrm{CH} 4$, Science, doi:10.1126/science.aad2705, 2016.

Seibert, P. and Frank, A.: Source-receptor matrix calculation with a Lagrangian particle dispersion model in backward mode, Atmos. Chem. Phys., 4, 51-63, doi:10.5194/acp-4-51-2004, 2004.

Shakhova, N., Semiletov, I., Salyuk, A., Yusupov, V., Kosmach, D., and Gustafsson: Extensive Methane Venting to the Atmosphere from Sediments of the East Siberian Arctic Shelf, Science, 327, 1246-1250, doi:10.1126/science.1182221, 2010.

Shakhova, N., Semiletov, I., Sergienko, V., Lobkovsky, L., Yusupov, V., Salyuk, A., Salomatin, A., Chernykh, D., Kosmach, D., Panteleev, G., Nicolsky, D., Samarkin, V., Joye, S., Charkin, A., Dudarev, O., Meluzov, A., and Gustafsson, O.: The East Siberian Arctic Shelf: towards further assessment of permafrost-related methane fluxes and role of sea ice, Philos. T. Roy. Soc. A, 373, 20140451, doi:10.1098/rsta.2014.0451, 2015.

Smith, M. L., Kort, E. A., Karion, A., Sweeney, C., Herndon, S. C. and Yacovitch, T. I.: Airborne Ethane Observations in the Barnett Shale: Quantification of Ethane Flux and Attribution of Methane Emissions, Environ. Sci. Technol., 49, 8158-8166, doi:10.1021/acs.est.5b00219, 2015.

Spahni, R., Joos, F., Stocker, B. D., Steinacher, M., and Yu, Z. C.: Transient simulations of the carbon and nitrogen dynamics in northern peatlands: from the Last Glacial Maximum to the 21st century, Clim. Past, 9, 1287-1308, doi:10.5194/cp-9-1287-2013, 2013.

Stocker, B. D., Spahni, R., and Joos, F.: DYPTOP: a costefficient TOPMODEL implementation to simulate sub-grid spatio-temporal dynamics of global wetlands and peatlands, Geosci. Model Dev., 7, 3089-3110, doi:10.5194/gmd-7-30892014, 2014.

Stohl, A.: Computation, accuracy and applications of trajectories - A review and bibliography, Atmos. Environ., 32, 947-966, doi:10.1016/s1352-2310(97)00457-3, 1998.

Stohl, A., Forster, C., Frank, A., Seibert, P., and Wotawa, G.: Technical note: The Lagrangian particle dispersion model FLEXPART version 6.2, Atmos. Chem. Phys., 5, 2461-2474, doi:10.5194/acp-5-2461-2005, 2005.

Stohl, A., Kim, J., Li, S., O’Doherty, S., Mühle, J., Salameh, P. K., Saito, T., Vollmer, M. K., Wan, D., Weiss, R. F., Yao, B., Yokouchi, Y., and Zhou, L. X.: Hydrochlorofluorocarbon and hydrofluorocarbon emissions in East Asia determined by inverse modeling, Atmos. Chem. Phys., 10, 3545 3560, doi:10.5194/acp-10-3545-2010, 2010.

Stroeve, J., Holland, M. M., Meier, W., Scambos, T., and Serreze, M.: Arctic sea ice decline: Faster than forecast, Geophys. Res. Lett., 34, L09501, doi:10.1029/2007GL029703, 2007.

Suto, H. and Inoue, G.: A New Portable Instrument for In Situ Measurement of Atmospheric Methane Mole Fraction by Applying an Improved Tin Dioxide-Based Gas Sensor, J. Atmos. Ocean. Tech., 27, 1175-1184, doi:10.1175/2010JTECHA1400.1., 2010.

Thompson, R. L. and Stohl, A.: FLEXINVERT: an atmospheric Bayesian inversion framework for determining surface fluxes of trace species using an optimized grid, Geosci. Model Dev., 7, 2223-2242, doi:10.5194/gmd-7-2223-2014, 2014.

Thompson, R. L., Stohl, A., Zhou, L. X., Dlugokencky, E., Fukuyama, Y., Tohjima, Y., Kim, S. -Y., Lee, H., Nisbet, E. G., and Fisher, R. E.: Methane emissions in East Asia for 2000-2011 estimated using an atmospheric Bayesian inversion, J. Geophys. Res.-Atmos., 120, doi:10.1002/2014JD022394, 2015.

Tokida, T., Mizoguchi, M., Miyazaki, T., Kagemoto, A., Nagata, O., and Hatano, R.: Episodic release of methane bubbles from peatland during spring thaw, Chemosphere, 70, 165-171, doi:10.1016/j.chemosphere.2007.06.042, 2007.

Umezawa, T., Machida, T., Aoki, S., and Nakazawa, T.: Contributions of natural and anthropogenic sources to atmospheric methane variations over western Siberia estimated from its carbon and hydrogen isotopes, Global Biogeochem. Cy., 26, GB4009, doi:10.1029/2011GB004232, 2012.

van der Werf, G. R., Randerson, J. T., Giglio, L., Collatz, G. J., Mu, M., Kasibhatla, P. S., Morton, D. C., DeFries, R. S., Jin, Y., and van Leeuwen, T. T.: Global fire emissions and the contribution of deforestation, savanna, forest, agricultural, and peat fires (1997- 
2009), Atmos. Chem. Phys., 10, 11707-11735, doi:10.5194/acp10-11707-2010, 2010.

Whalen, S. C. and Reeburgh, W. S.: Interannual variations in tundra methane emission: A 4-year time series at fixed sites, Global Biogeochem. Cy., 6, 139-159, doi:10.1029/92GB00430, 1992.

Winderlich, J., Chen, H., Gerbig, C., Seifert, T., Kolle, O., Lavric, J. V., Kaiser, C., Höfer, A., and Heimann, M.: Continuous lowmaintenance $\mathrm{CO}_{2} / \mathrm{CH}_{4} / \mathrm{H}_{2} \mathrm{O}$ measurements at the Zotino Tall Tower Observatory (ZOTTO) in Central Siberia, Atmos. Meas. Tech., 3, 1113-1128, doi:10.5194/amt-3-1113-2010, 2010.

Worthy, D. E., Platt, J. A., Kessler, R., Ernst, M., and Racki, S.: Measurement Procedures and Data Quality, in Canadian Baseline Program, Summary of progress to 2002, 97-120, Meteorological Service of Canada., 2003
Xiong, X., Barnet, C., Maddy, E. S., Gambacorta, A., King, T. S., and Wofsy, S. C.: Mid-upper tropospheric methane retrieval from IASI and its validation, Atmos. Meas. Tech., 6, 2255-2265, doi:10.5194/amt-6-2255-2013, 2013.

Zona, D., Gioli, B., Commane, R., Lindaas, J., Wofsy, S. C., Miller, C. E., Dinardo, S. J., Dengel, S., Sweeney, C., Karion, A., Chang, R. Y., Henderson, J. M., Murphy, P. C., Goodrich, J. P., Moreaux, V., Liljedahl, A., Watts, J. D., Kimball, J. S., Lipson, D. A., and Oechel, W. C.: Cold season emissions dominate the Arctic tundra methane budget, P. Natl. Acad. Sci. USA, 113, 40-45, doi:10.1073/pnas.1516017113, 2016. 